\title{
Multilevel and multiscale drought reanalysis over France with the Safran-Isba-Modcou hydrometeorological suite
}

\author{
J.-P. Vidal ${ }^{1,2}$, E. Martin ${ }^{1}$, L. Franchistéguy ${ }^{3}$, F. Habets ${ }^{4}$, J.-M. Soubeyroux ${ }^{3}$, M. Blanchard ${ }^{3}$, and M. Baillon ${ }^{3}$ \\ ${ }^{1}$ CNRM/GAME, Météo-France and CNRS, URA 1357, 42 avenue Coriolis, 31057 Toulouse Cedex 1, France \\ ${ }^{2}$ Cemagref, UR HHLY, 3 bis quai Chauveau - CP 220, 69336 Lyon, France \\ ${ }^{3}$ Météo-France, Direction de la Climatologie, 42 avenue Coriolis, 31057 Toulouse Cedex 1, France \\ ${ }^{4}$ UMR-SISYPHE, Mines-ParisTech, Centre de Géosciences, équipe SHR, 35 rue St Honoré, 77305 Fontainebleau, France
}

Received: 5 October 2009 - Published in Hydrol. Earth Syst. Sci. Discuss.: 22 October 2009

Revised: 2 March 2010 - Accepted: 2 March 2010 - Published: 9 March 2010

\begin{abstract}
Physically-based droughts can be defined as a water deficit in at least one component of the land surface hydrological cycle. The reliance of different activity domains (water supply, irrigation, hydropower, etc.) on specific components of this cycle requires drought monitoring to be based on indices related to meteorological, agricultural, and hydrological droughts. This paper describes a high-resolution retrospective analysis of such droughts in France over the last fifty years, based on the Safran-Isba-Modcou (SIM) hydrometeorological suite. The high-resolution 1958-2008 Safran atmospheric reanalysis was used to force the Isba land surface scheme and the hydrogeological model Modcou. Meteorological droughts are characterized with the Standardized Precipitation Index (SPI) at time scales varying from 1 to 24 months. Similar standardizing methods were applied to soil moisture and streamflow for identifying multiscale agricultural droughts - through the Standardized Soil Wetness Index (SSWI) - and multiscale hydrological droughts, through the Standardized Flow Index (SFI). Based on a common threshold level for all indices, drought event statistics over the 50-yr period - number of events, duration, severity and magnitude - have been derived locally in order to highlight regional differences at multiple time scales and at multiple levels of the hydrological cycle (precipitation, soil moisture, streamflow). Results show a substantial variety of temporal drought patterns over the country that are highly dependent on both the variable and time scale considered. Independent spatio-temporal drought events have then been identified and described by combining local characteristics with the evolution of area under drought. Summary statistics
\end{abstract}

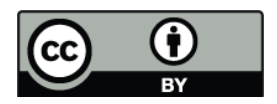

Correspondence to: J.-P. Vidal (jean-philippe.vidal@cemagref.fr) have finally been used to compare past severe drought events, from multi-year precipitation deficits (1989-1990) to short hot and dry periods (2003). Results show that the ranking of drought events depends highly on both the time scale and the variable considered. This multilevel and multiscale drought climatology will serve as a basis for assessing the impacts of climate change on droughts in France.

\section{Introduction}

Severe drought events occurred in Europe over the last few decades and they had extensive socio-economic impacts (European Commission, 2007). In France, the cost of such events has been estimated at 500 million euros each year on average since 1989, and up to 2.5 billion euros for 2003 only (Buisson, 2007). Droughts can have economic impacts on water supply, industry, energy, agriculture, navigation, but also social and environmental impacts. Numerous sectors are potentially affected through water deficits in different components of the land surface hydrological cycle: filling of high-elevation reservoirs mainly depends on precipitation, agriculture is directly related to soil moisture, and drinkable water supply relies on streamflows and aquifers. Different types of physical droughts can therefore be defined depending on the hydrological variable considered. Three types have for example been defined by Wilhite and Glantz (1985): meteorological drought, agricultural drought and hydrological drought. The propagation of a drought event through the hydrological cycle should thus be assessed through the evaluation of water deficits at those three levels. Also, depending on the socio-economic sector considered, water deficits will have impacts over different time scales, so characterizing

Published by Copernicus Publications on behalf of the European Geosciences Union. 
a drought in a comprehensive way would require the analysis of multiple time scales as proposed by McKee et al. (1995). Finally, the area affected by a drought - the spatial dimension - is essential for regional water management (see for example Vicente-Serrano, 2006).

The aim of this paper is to characterize droughts in France over the last $50 \mathrm{yrs}$ along the three dimensions noted above: (1) levels of the hydrological cycle (precipitation, soil moisture, streamflow), (2) time scale and (3) spatial scale. Many studies have attempted to tackle separately the issues associated with these three dimensions. The US National Drought Mitigation Center for example provides an estimate of drought severity based on a subjective multi-index classification scheme, which includes indices of all three types of droughts (Svoboda et al., 2002). Besides, some indices like the Standardized Precipitation Index (SPI, McKee et al., 1993) allow the consideration of different time scales for assessing meteorological droughts. The spatial consistency offered by some indices was furthermore used for spatial drought assessment in Europe at the meteorological level (Lloyd-Hughes and Saunders, 2002), at the agricultural level (Dutra et al., 2008) and at the hydrological level (Stahl, 2001; Zaidman et al., 2002).

However, very few large-scale assessments of the spatiotemporal development of droughts have been made jointly for different components of the hydrological cycle. Within the ARIDE (Assessment of the Regional Impact of Droughts in Europe) European project, Hisdal and Tallaksen (2003) carried out a regional assessment of meteorological and hydrological droughts in Denmark. More recently, LloydHughes et al. (2009a) derived two drought catalogues over 22 European regions (Stahl and Demuth, 1999; Prudhomme and Sauquet, 2007): one describes meteorological droughts using a regional version of the SPI, and the other describes hydrological droughts with the Regional Deficiency Index (RDI, Stahl, 2001) computed from observed streamflows. At the catchment scale, Tallaksen et al. (2009) studied drought propagation through the hydrological cycle by evaluating water deficits in precipitation, groundwater recharge, hydraulic head and discharge in a groundwater fed catchment located in England.

In addition, few studies considered different time scales, and most of them focused on meteorological droughts and were based on the SPI (see for example Loukas and Vasiliades, 2004; Vicente-Serrano and López-Moreno, 2005). A notable exception is the study by Andreadis et al. (2005) which assessed historical US agricultural and hydrological droughts at different time scales by using percentiles of soil moisture and runoff computed with the VIC macroscale hydrological model (Liang et al., 1994). Sheffield et al. (2009) extended this multiple time-scale assessment of soil moisture droughts at the global scale.

This paper proposes an approach for jointly and consistently characterizing meteorological, agricultural and hydrological droughts at different time scales over France. This research is part of the CLIMSEC project that aims at assessing the impact of climate change on droughts in France (Vidal and Moisselin, 2008; Vidal and Soubeyroux, 2008). Drought identification and characterization over the last $50 \mathrm{yr}$ is based on precipitation, soil moisture and streamflow outputs from the Safran-Isba-Modcou (SIM) hydrometerological suite, and makes use of drought indices inspired from SPI computation procedures.

Section 2 introduces the SIM hydrometeorological reanalysis and describes drought indices and procedures applied to identify spatially and temporally independent drought events. Section 3 first provides an overview of dry periods experienced in France between 1958 and 2008, and Sect. 4 provides examples of drought propagation through the hydrological cycle. Characteristics of severe drought events are then explored at the local scale (Sect. 5) in order to answer four fundamental questions about such events:

- How often do they occur?

- When do they start?

- How long do they last?

- How severe are they?

Spatio-temporal drought events are then identified and compared at the national scale in order to extract benchmark events over the last $50 \mathrm{yr}$ (Sect. 6). Results are finally discussed in Sect. 7.

\section{Data and methods}

This section first presents the Safran-Isba-Modcou (SIM) hydrometeorological suite and then details the drought indices developed in this study and their use to identify drought events.

\subsection{Safran-Isba-Modcou}

The SIM suite and its validation over France are described in detail by Habets et al. (2008). Its components are thus briefly described in the paragraphs below.

Safran is an atmospheric analysis system that computes vertical profiles of the atmosphere for climatically homogeneous zones, by combining large-scale fields and ground observations through Optimal Interpolation (Gandin, 1965). The algorithm, its validation and its application over France are detailed by Quintana-Seguí et al. (2008). Vidal et al. (2010) have applied Safran over the period 1958-2008 to constitute a $50-\mathrm{yr}$ high-resolution atmospheric reanalysis over France. Safran hourly outputs of liquid and solid precipitation, air temperature, specific humidity, wind speed, visible and infrared radiations are interpolated on a $8-\mathrm{km}$ regular grid to provide atmospheric forcings for land surface schemes. A detailed validation of this 50-yr atmospheric 
reanalysis over France has been carried out by Vidal et al. (2010). Of particular interest to this study, they found that the reanalysis uncertainty on precipitation is both very low and relatively constant over the 50 -yr period when considering both dependent and independent data. The 50-yr average monthly bias with respect to 83 high-quality validation stations is slightly positive $(+1 \mathrm{~mm})$, with an interannual standard deviation of $2.7 \mathrm{~mm}$.

The land surface scheme Isba computes water and energy budgets at the soil-vegetation-atmosphere interface (Noilhan and Mahfouf, 1996). This scheme is used in Météo-France numerical weather prediction and climate models. The configuration of this highly modular scheme is the same as the one used by Habets et al. (2008). Isba is based on a threelayer force-restore (i.e. forcing with short time scales at the surface and restore towards deep soil values evolving more slowly with time) model and explicit multilayer snow model and it includes subgrid runoff and drainage schemes. Soil and vegetation parameters are derived from the Ecoclimap database (Masson et al., 2003). Isba has here been run over France from 1 August 1958 to 31 July 2008 with forcings from Safran atmospheric reanalysis. Snowpack, soil temperature and soil moisture values have been initialized using a 2yr spin-up (first year repeated three times). One output relevant for the present study is the Soil Wetness Index (SWI) defined as:

$\mathrm{SWI}=\frac{w_{\mathrm{tot}}-w_{\text {wilt }}}{w_{\mathrm{fc}}-w_{\text {wilt }}}$

where $w_{\text {tot }}$ is the volumetric water content of the simulated soil column, $w_{\mathrm{fc}}$ the water content at field capacity and $w_{\text {wilt }}$ the water content at wilting point. Soil moisture products from Isba have been extensively validated against in situ measurements (Habets et al., 1999; Paris Anguela et al., 2008) as well as various satellite products (Baghdadi et al., 2007; Albergel et al., 2008; Rüdiger et al., 2009).

Modcou is a distributed hydrogeological model that computes the evolution of multi-layered aquifers and surface flows (Ledoux et al., 1989). Modcou uses drainage and runoff values simulated by Isba to compute the daily evolution of the three-layer Seine aquifer and the single-layer Rhône aquifer, as well as 3-hourly river flows for 907 hydrometric stations in France plus 256 sea outlets. A steady state of aquifers has been computed to provide the initial condition for the 50-yr run forced by Isba outputs. Hydrological outputs of the SIM suite have been validated against observed river flows and water table levels over a $10-\mathrm{yr}$ period by $\mathrm{Ha}-$ bets et al. (2008). They found in particular that simulated versus observed discharge ratios are very close to 1 for large basins, with spatial scales corresponding to that of drought events.

Figure 1 shows some characteristics of Isba and Modcou models that are useful for interpreting spatial results of drought characteristics: soil properties (defined only by percentage of clay and sand, see Noilhan and Lacarrère, 1995),
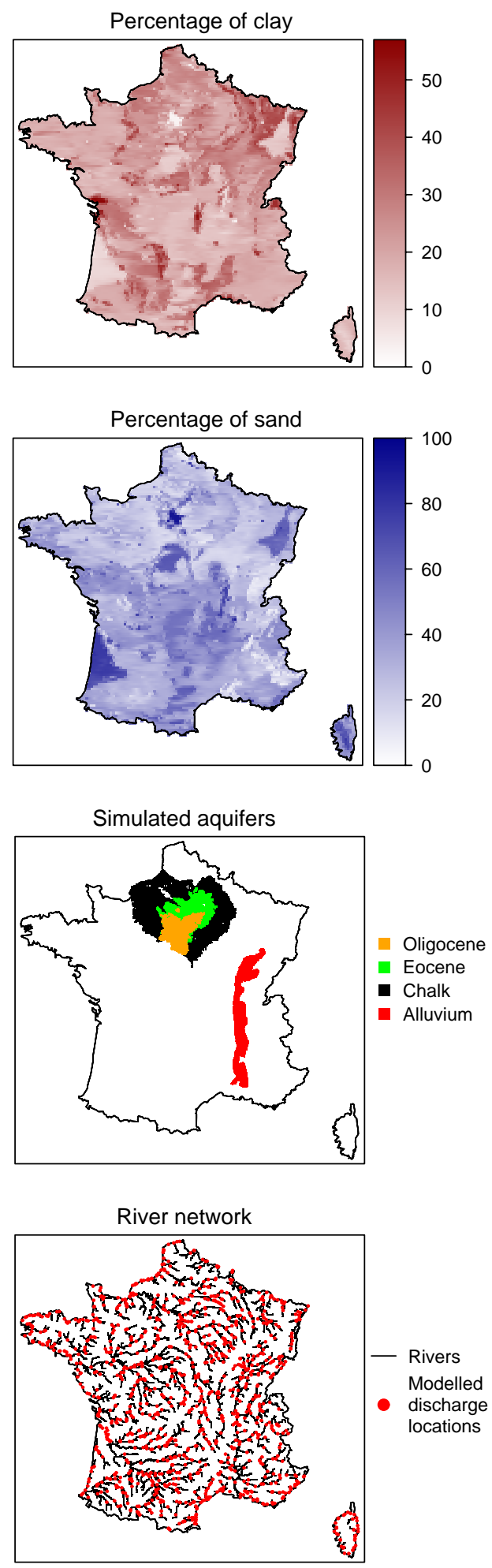

Fig. 1. Characteristics of Isba and Modcou. From top to bottom: percentage of clay in Isba soil column, percentage of sand, extent of aquifers explicitly simulated by Modcou and Modcou river network and output cells. 
Table 1. Correspondence between SIM variables and drought types defined by Wilhite and Glantz (1985).

\begin{tabular}{lll}
\hline & Variable & Drought type \\
\hline Safran & Precipitation & Meteorological \\
Isba & Soil Wetness Index & Agricultural \\
Modcou & Streamflow & Hydrological \\
\hline
\end{tabular}

underground aquifers and surface network. Other characteristics, among them those related to vegetation, can be found in Habets et al. (2008).

\subsection{Drought indices}

Three variables among all SIM outputs are considered here: total precipitation from Safran, SWI from Isba and streamflow from Modcou. These variables, aggregated to the monthly scale, are used to evaluate the three types of physical droughts, as summarized in Table 1.

\subsubsection{Review of standardized indices}

The approach used here is inspired from the computation of the Standardized Precipitation Index. The procedure for computing SPI from a given precipitation time series requires fitting the cumulative precipitation over $n$ month(s) to a given statistical distribution. This fitting is done separately for each ending month in order to take account of seasonal differences in distributions (McKee et al., 1993). Fitted cumulative distributions are then equiprobably transformed into a standard normal distribution. This correspondence is finally used to transform cumulative precipitation time series to SPI time series.

The SPI has been used to provide a spatial assessment of historical meteorological droughts in various parts of Europe: Catalonia region in Spain (Lana et al., 2001), Iberian Peninsula (Vicente-Serrano, 2006), Basilicata region in Italy (Piccarreta et al., 2004), Thessaly region in Greece (Loukas and Vasiliades, 2004), the Czech Republic (Trnka et al., 2009), both Sicily and the Elbe basin in Germany (Bordi et al. , 2004), and the whole of Europe at relatively coarse resolution (Lloyd-Hughes and Saunders, 2002). No nationalscale high-resolution assessment has been made on past meteorological droughts in France, whether with SPI or other drought indices.

The SPI computation procedure has been recently applied to runoff time series for a basin in California (Shukla and Wood, 2008) and to streamflow time series for the Tagus river in the Iberian Peninsula (López-Moreno et al., 2009). Related normalization procedures have also been applied for deriving agricultural droughts based on monthly quantiles of modelled soil moisture. Based on a 50-yr retrospective hydrological simulation of the land surface budget of the
Table 2. Summary of drought indices, corresponding computation domain and time scales considered.

\begin{tabular}{llc}
\hline Index & Domain & $\begin{array}{c}\text { Time scale } \\
\text { (months) }\end{array}$ \\
\hline SPI & 8602 grid cells & $1-24$ \\
SSWI & 8602 grid cells & $1-24$ \\
SFI & 1163 locations & $1-24$ \\
\hline
\end{tabular}

continental USA with the VIC model (Maurer et al., 2002), Sheffield et al. (2004) and Andreadis et al. (2005) used percentiles of simulated soil moisture and runoff for identifying dry periods and characterize agricultural and hydrological drought events. A similar methodology was applied at the global scale by Sheffield and Wood (2007) for assessing past agricultural drought events.

This normalization approach provide indices relative to a mean baseline (hydro-)climate. It is therefore different from approaches generating indices with absolute values (e.g., streamflow deficits in $\mathrm{m}^{3}$ ), like the threshold level approach described by Hisdal et al. (2004) for hydrological droughts.

\subsubsection{Approach}

In this paper, we applied a SPI-like computation procedure to total precipitation, soil moisture and streamflow simulated by the SIM hydrometeorological suite to derive three types of indices: the Standardized Precipitation Index (SPI) itself, the Standardized Soil Wetness Index (SSWI) and the Standardized Flow Index (SFI). Table 2 summarizes the computation domain of each type of index and the time scales considered for computation. SSWI has thus for example been computed for 8602 grid cells covering France, from time series of SWI averaged over periods of 1 to 24 months.

A critical step in the procedure is the fitting to a given statistical distribution of monthly variables. Based on a $0.5^{\circ}$ gridded dataset, Lloyd-Hughes and Saunders (2002) found gamma distributions suitable for the larger part of Europe. However, the Pearson Type III distribution recommended by Guttman (1999) has been found more appropriate over some parts of the Iberian Peninsula (Vicente-Serrano, 2006). Statistical distributions chosen for modelling monthly soil moisture are even more varied in the literature: beta distributions based on $L$-moments (Sheffield et al., 2004; Sheffield and Wood, 2007), empirical distributions (Andreadis et al., 2005; Wang et al., 2009), gaussian distributions for soil moisture anomalies (Mo, 2008), etc. As for monthly runoff, Shukla and Wood (2008) recommended a great care when choosing among the potentially suitable distributions after having tested different theoretical distributions (gamma, log-normal, etc.). As a matter of fact, choosing a poorly adapted distribution may lead to large discrepancies in estimating extreme percentiles and thus corresponding drought index values. 
In this study, the dimensions of the problem (24 time scales $\times 12$ calendar months for each grid cell/station) prevented one to find the most appropriate type of theoretical distribution for each time series. Moreover, the shape of soil moisture distribution is highly variable depending on climate and soil characteristics and can be bimodal, which expresses preferential states of seasonal soil moisture (Rodriguez-Iturbe et al., 1991; D’Odorico et al., 2000). This may yield to large uncertainties in fitting monthly distributions to unimodal theoretical distributions. The choice was therefore made here to apply a flexible nonparametric approach. Empirical distributions were thus fitted with kernel density estimates with gaussian kernel (Wilks, 2006, p. 35 ). This approach enables generating continuous distributions close to the empirical ones, which are reasonably well defined thanks to the 50-yr sample size. Moreover, features like bimodal and bounded distributions of SWI can be readily handled. For precipitation and streamflow, kernel densities were estimated with a zero lower bound, and for the SWI they were estimated within an interval defined with Eq. (1) by $w_{\text {tot }}=0$ and $w_{\text {tot }}=w_{\text {sat }}$, where $w_{\text {sat }}$ is the soil water content at saturation.

\subsection{Drought event identification and description}

The procedure described above helped generating space-time fields of drought index values, for each drought type and each time scale considered. An overview of these fields is presented in Sects. 3 and 4. The next step in drought characterization consisted in identifying drought events. The paragraphs below describe the approach used for determining the characteristics of these events at both the local and the national scales, the results of which are presented in Sects. 5 and 6.

\subsubsection{Local scale}

At the local scale, i.e. for a drought index time series over a grid cell or location, the procedure adopted corresponds to the one proposed initially by McKee et al. (1993): a drought event is defined as a period in which the index is continuously negative and it reaches a given threshold. In order to identify only the most severe events while keeping a reasonable number of events, the threshold for identifying localscale drought events is taken as $\simeq-0.84$, which corresponds to a probability of occurrence of $20 \%$ in the standard normal distribution, which is by construction the distribution in time of any drought index (SPI, SSWI, SFI) for a given location. A similar threshold value has been chosen by Andreadis et al. (2005) in their analysis of US soil moisture and streamflow droughts and by Wang et al. (2009) in the multimodel reconstruction of US soil moisture droughts, following monitoring practice of the US Climate Prediction Center. A more extreme threshold ( $\simeq-1.64$ ) corresponding a $5 \%$ probability will also be used in Sect. 3 for emphasizing very dry periods in a synthetic representation.

Figure 2 shows an example of local-scale characteristics of drought events: the duration of an event is the number of months where the index is continuously negative; its severity is the absolute value of the minimum reached during the event; and the magnitude of the event is the absolute value of the sum of index values during the event. Additional information on the timing of an event can also be extracted from the index time series, and we here focused on the starting month of the drought.

Computing drought event characteristics for each output location allows assessing the regional differences in drought characteristics, as done by Soule (1992) in the USA with Palmer (1965) indices. The results of this regional assessment for SPI, SSWI and SFI at different time sales are given in Sect. 5.

\subsubsection{National scale}

Droughts develop in both space and time, and SPI and SSWI fields computed here allow to take account of the areal dimension of the event, and its evolution with time. A drought event is here considered as a sequence of spatially contiguous and temporally continuous areas where the index is under a given threshold value. A threshold corresponding to a local $20 \%$ probability $(\simeq-0.84$ ) has been chosen for identifying spatio-temporal drought events following Andreadis et al. (2005) and Sheffield et al. (2009). An algorithm for identifying independent drought events - understood here as non-overlapping in both space and time - has been implemented and applied to continental France (without Corsica, in order to preserve a spatial consistency of events). This algorithm, modified after Andreadis et al. (2005), first identifies at each time step spatial clusters of drought areas (see Santos et al., 2000, 2002, for a description of the clustering process). Small isolated areas, with less than 10 contiguous cells, i.e. $640 \mathrm{~km}^{2}$, are removed from the subsequent calculations. Clusters from successive time steps are then linked with each other in a recursive way in order to identify merging or breaking up areas as parts of the same spatio-temporal event. Two clusters are considered to belong to the same event if the overlapping area between the two time steps is higher than 100 cells $\left(6400 \mathrm{~km}^{2}\right)$. The drought event identification algorithm has been applied to SPI and SSWI spatiotemporal fields at all time scales.

Independent events can then be compared with each other by adding the spatial dimension to local-scale characteristics described in Fig. 2. Adopted summary statistics for an event include its mean duration, its mean area and its total magnitude. The mean duration of a spatio-temporal event is defined as the mean duration of all cells across the country affected by the drought at some time(s) during the event. The duration for each cell is taken here as the number of months when the index is lower than the threshold (in 


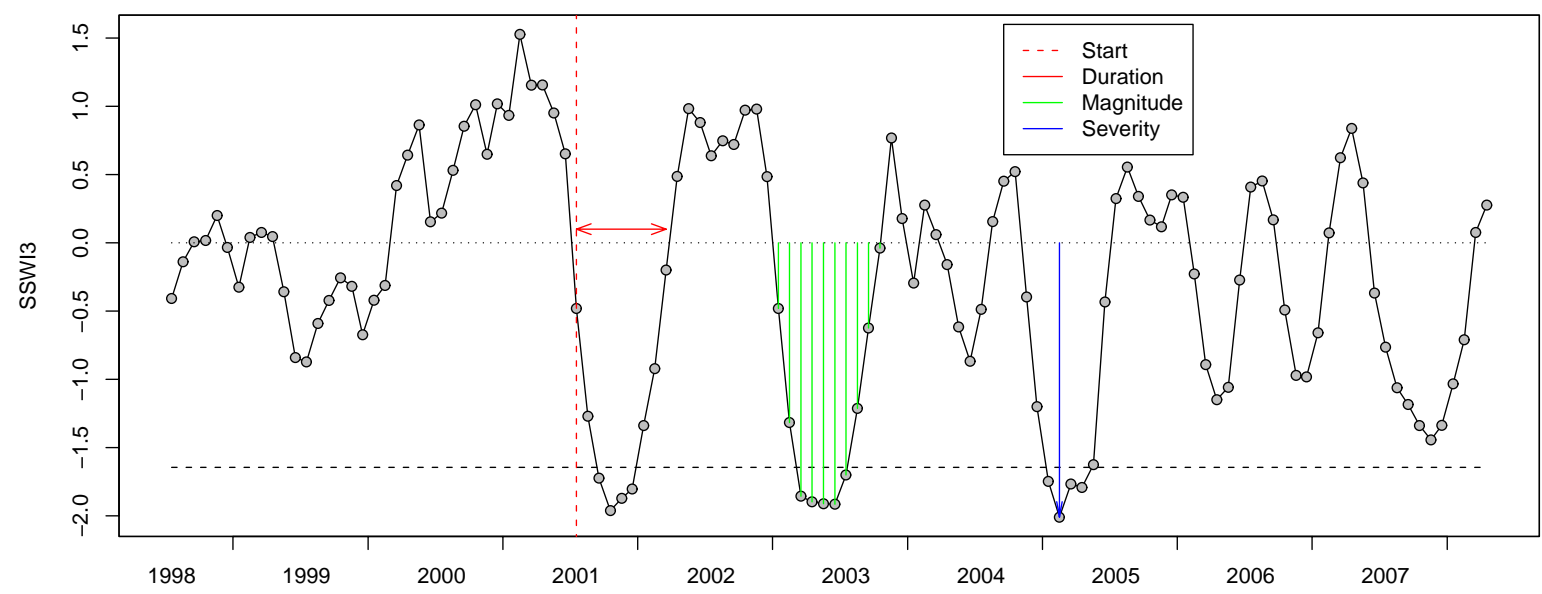

Fig. 2. Definition of local-scale characteristics of drought events: start, duration, magnitude and severity. Example of a 10-yr evolution of SSWI3 for a grid cell located near Toulouse (South-West France). Three severe events reach here a 5\% probability threshold shown with a dashed line.

possibly separate periods). The mean area is defined as the mean drought-affected area during the event, and expressed as a percentage of the total area of France. The total magnitude is computed here as the sum over space and time of the index values in cells affected by the event, expressed in month times percent of France area. Section 6.1 presents the inter-comparison of national-scale drought events through these summary statistics.

The final part of the study aimed at finding benchmark drought events, i.e. events that led to the maximum deficits averaged over a given area within the last $50 \mathrm{yr}$. We here followed the approach of Andreadis et al. (2005) who introduced Severity-Area-Duration (SAD) curves to characterize spatio-temporal soil moisture and runoff drought events in the conterminous United States. SAD curves are an adaptation of the depth-area-duration method for design storm analysis (WMO, 1969), and they have been used to compare global-scale agricultural drought events by Sheffield et al. (2009). The output for each event and each duration considered is a curve showing the minimum value of the index - usually its absolute value - as a function of the area. SAD curves as computed by Andreadis et al. (2005) suffer however from an artificial reduction in severity with long durations (time scales) and resulting from the time-averaging of index values coming from a single one-month-average index field. We here modified this approach by taking advantage of the fields computed at different time scales to draw SeverityArea-Time Scale (SAT) curves. In this way, the relationship between the area and the mean severity can be directly compared across different time scales for each event. The use of SAT curves for the definition of benchmark drought events will be presented in Sect. 6.2.

\section{Overview of dry periods}

France experienced a number of dry periods within the last $50 \mathrm{yrs}$ that have been listed and documented mainly at the meteorological level (see for example Besleaga, 1992) or through their impacts on human activities (Le Roy Ladurie, 2009). Figure 3 provides an overview of such periods by plotting the area affected by meteorological, agricultural and hydrological drought in France when considering 3-month and 12-month indices. A very low probability threshold $(\simeq-1.64$, i.e. $5 \%$ probability) is here considered in order to emphasize very dry periods.

This synthetic representation with a low threshold level emphasizes periods with both severe and widespread deficits across the country like 1976 or the three consecutive years 1988-1990. The different levels of the hydrological cycle exhibit correlated but different drought patterns at the 3-months time scale: soil moisture deficits are generally less extensive or less severe (with reduced peaks) than corresponding precipitation deficits, and periods with streamflow deficits appear to combine characteristics from both precipitation and soil moisture deficits. When looking at 12-month deficits, various differences can be spotted as a consequence of the larger time scale integration: first, many peaks disappear at all levels, like in 1978 or 1985; dry periods last longer or are shifted in time with respect to corresponding periods identified with 3-month indices; the 1998-1990 period exhibits much larger deficits than with 3-month indices.

All these observations highlight the differences in dry period characteristics obtained when using indices based on various hydrological variables and with different time scales. It thus emphasizes the need to consider different variables over different time scales in order to completely characterize a drought. The remainder of this article will therefore show 


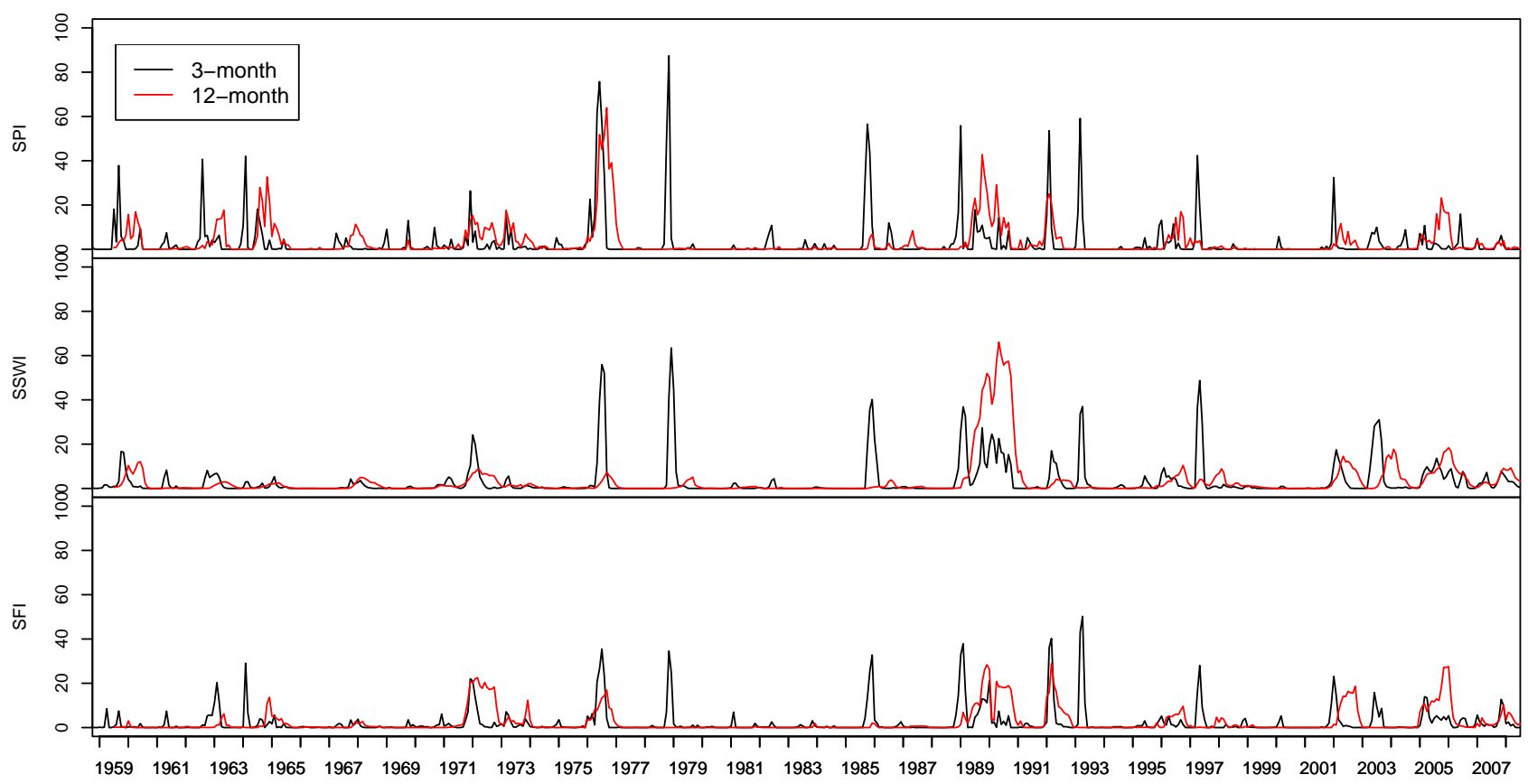

Fig. 3. Area affected by drought as a percentage of France area (SPI and SSWI) or percentage of hydrometric stations (SFI) with 3-month and 12-month indices under a threshold of $5 \%$.

results for all three drought indices and at time scales of 3 , 6 and 12 months, except in the next section where only the 3-month time scale will be considered.

\section{Examples of drought propagation through the hydrological cycle}

Figures 4 and 5 show two contrasted examples of drought propagation through the land surface hydrological cycle for two dry 12-month periods: November 1975 to October 1976 and February 2003 to January 2004. Both figures use a colour scale associated with the original SPI classification proposed by McKee et al. (1993) and recalled in Table 3. The time scale chosen for illustrating drought propagation features is 3 months.

The spatio-temporal development of hydrological droughts will be here qualitatively compared with results obtained by Lloyd-Hughes et al. (2009b) and Hannaford et al. (2009) with the Regional Deficiency Index (RDI) over 6 homogenous regions defined by Prudhomme and Sauquet (2007): Northern France, North-East France, Western and Central France, Pyrenees, Southern France, and French Southern Alps. The RDI, described in detail by Stahl (2001), is based on binary deficiency index time series (over or under a given threshold that varies with the day of the year) computed from observed streamflow time series at each station within a region. The proportion of hydrometric stations experiencing a drought gives the RDI for this region. Such a comparison is specially relevant as it brings together
Table 3. Drought classification by index value (McKee et al., 1993).

\begin{tabular}{ll}
\hline Index value & Drought category \\
\hline 0 to -0.99 & Mild \\
-1 to -1.49 & Moderate \\
-1.5 to -1.99 & Severe \\
-2 or less & Extreme \\
\hline
\end{tabular}

drought assessments derived from observed streamflow (RDI) and from streamflow computed by Modcou (SFI). Moreover, assessing SFI results against an independent hydrological drought index enables to identify possible discrepancies resulting from the way drought propagation through the whole hydrological cycle is modelled with the SIM hydrometeorological suite.

\subsection{6}

Figure 4 shows that the 1976 meteorological drought actually started in December 1975, with relatively high precipitation deficits until April 1976. It reached a peak in May-June-July before a rather quick recovery in August (for the southern half of the country) and September (Brochet, 1976). It has to be noted that the Mediterranean region has been spared by these precipitation deficits throughout the whole period, and in particular in summer (see Briffa et al., 1994, for summeraveraged PDSI maps over the period 1891-1991). 


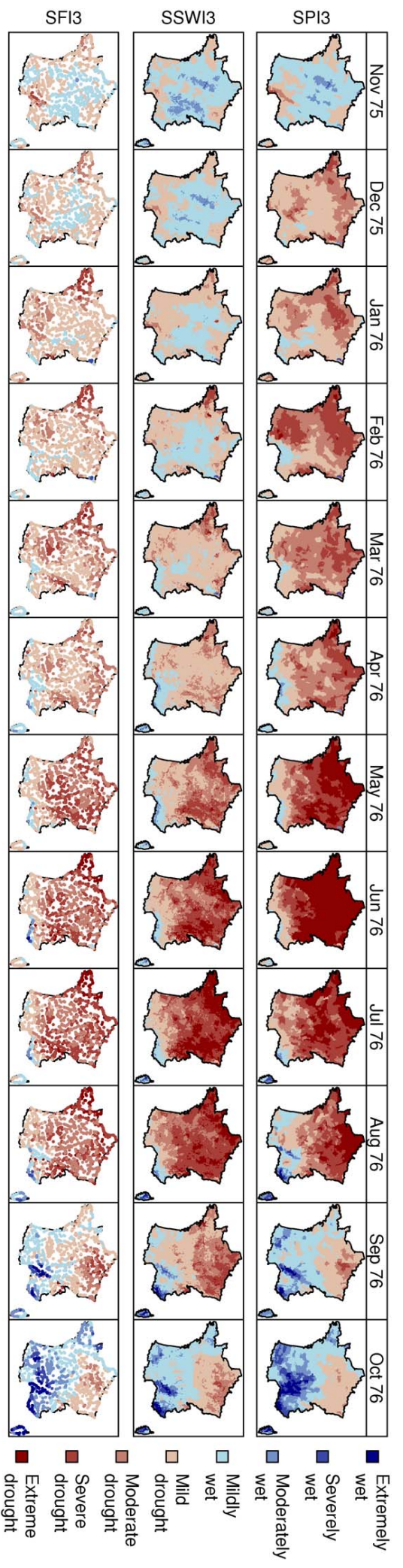

Fig. 4. Evolution of 1976 drought with 3-month indices, from November 1975 to October 1976. Colour key match classes defined in Table 3.

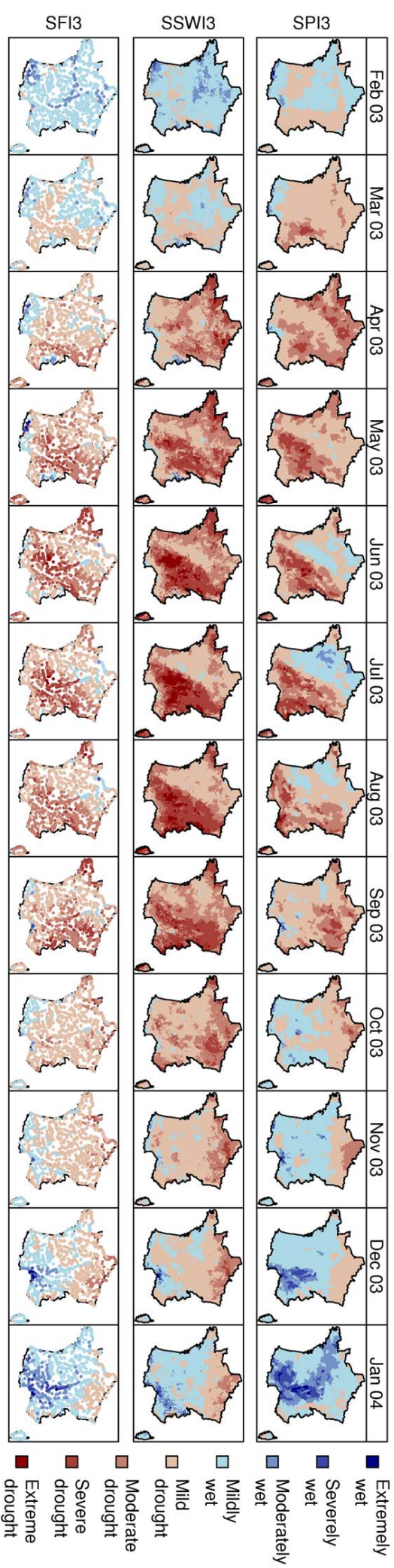

Fig. 5. As for Fig. 4 but for 2003 drought, from February 2003 to January 2004. 
Several differences can be identified with the evolution of the subsequent agricultural drought: first, it actually started to spread much later (May) due to a satisfactory refill of the soil water reservoir during the previous Autumn season (not shown). Vegetation thus made use of this stock during the Spring growing season until depletion of the soil water content. The recovery period also differs from the meteorological drought, with September soil moisture deficits still very high in the northern part of the country (see Choisnel, 1977, for an analysis of soil water content at a 10-day step). This illustrates well the slow response of soils to precipitation after a very dry period. The specific case of Brittany (northwest of the country) can also be spotted with early Spring soil moisture deficits due to already severe winter precipitation deficits (Mounier, 1977). The latter deficits also led to extremely low flows in Brittany in late Winter and early Spring (Bremond, 1976). It has to be noted that one-month shifts may appear between the respective recovery date of the meteorological and agricultural drought when substantial precipitation only occurs at the very end of a month.

The large-scale hydrological drought however only started in May and lasted until September (see Zaidman et al., 2002, for a larger European perspective), coinciding in dynamics and severity with the agricultural drought. This three-step spatio-temporal behaviour (Brittany, then the main part of France and finally the northern half of the country) of the 1976 hydrological drought has already been noted by Zaidman and Rees (2000). Lloyd-Hughes et al. (2009b) found a very similar spatio-temporal pattern for this hydrological drought, except that they could not identify the first step due to the delineation of the "Western and Central France" region that includes both Brittany and the upper Loire basin. In accordance with the present study, they found that this region and the "North-East France" region were most severely affected from May to July, whereas the "Northern France" region has been mainly affected from June to September. Lloyd-Hughes et al. (2009b) also found that all three southern regions were mostly spared from this drought event.

\subsection{3}

As shown by Fig. 5, the 2003 meteorological drought can be broken down into three separate steps: first, generalized and rather limited precipitation deficits from March to May, then very high deficits over the south-eastern half of the country from June to August and finally a recession of the drought in the northern part of France lasting till November. The timing of the drought was thus quite different from year 1976, without winter precipitation deficits.

The onset of the agricultural drought (April) was quite synchronous with that of the meteorological drought, in contrast with year 1976. Soil moisture deficits were particularly high in the south-western half of the country (plus Brittany) during the whole summer and till September. These deficits were much more pronounced than precipitation deficits, due to large positive temperature anomalies, not only in August when the heat wave reached a peak $\left(+4.4^{\circ} \mathrm{C}\right.$ relative to the 1971-2000 average, see Bessemoulin et al. , 2004), but also over the whole summer (higher than $+4.5^{\circ} \mathrm{C}$ relative to the 1901-1995 average for a large part of France, see Luterbacher et al., 2004). van der Schrier et al. (2007) showed that a large part of the Greater Alpine Region was also affected by such soil moisture deficits at the annual time scale. As for the year 1976, the effects of soil memory can be identified in Fig. 5 through the longer recovery in the northern part of France.

The hydrological drought was generally less intense than the agricultural drought across France and it affected most severely Brittany, the Massif Central region (central mountain range) and the Jura mountain range (north-east). It was for example particularly severe on the upstream part of the Loire basin (Massif Central) where low-flow values dropped below those of 1976 (Moreau, 2004). The spatiotemporal development of the 2003 hydrological drought compares well with RDI results obtained by Lloyd-Hughes et al. (2009a): the "Western and Central France" and "Southern France" regions encompassing Brittany and the Massif Central mountain range have been mostly affected from May to July, and the "North-East France" region from June to September.

\section{Local-scale drought characteristics}

Results from the local drought identification procedure detailed in Sect. 2.3 are here presented in a spatialized way in order to answer the four fundamental questions about severe drought events (frequency, timing, duration and magnitude) mentioned in Sect. 1. The following paragraphs provide elements of response and aim at highlighting regional specificities at different time scales and at different levels of the hydrological cycle. All drought characteristics presented here - as well as all other conclusions of this work - are based on modelled variables computed by the SIM hydrometeorological suite. In order to remove the influence of the numerous mild drought events, only severe droughts - defined here as events with severity higher than the $20 \%$ threshold level (severity $>0.84$ ) - are considered here.

\subsection{Frequency}

Figure 6 plots the number of severe drought events having occurred during the 50-yr period, for all drought indices at three different time scales. The different colour scales chosen for each time scale first exemplify the approximately inverse relationship between the number of events and the time scale that has been previously noted by McKee et al. (1993) on SPI time series. The spatial variability in the number of events is rather limited for SPI at the 3-month and 6-month time scales, and the northern part of France seem to experience 


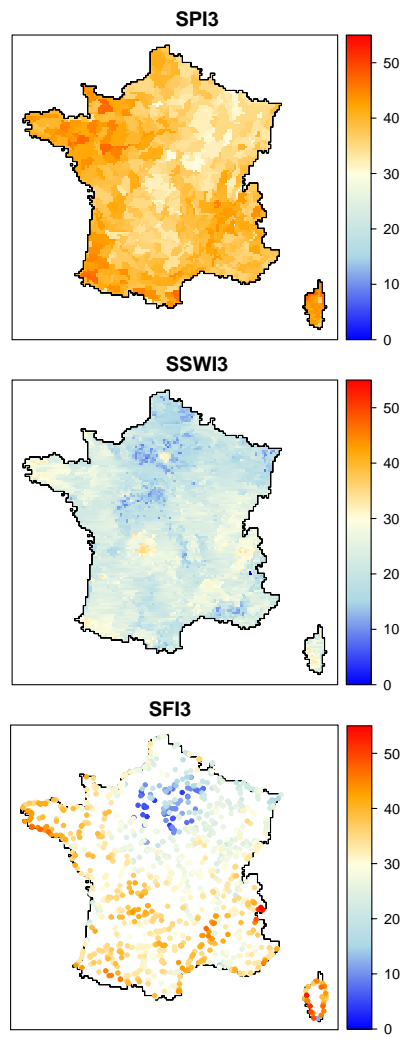

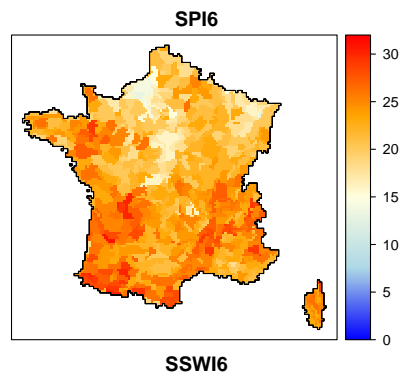
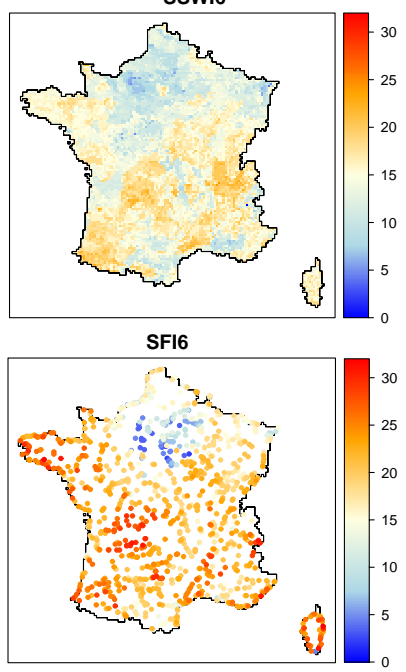

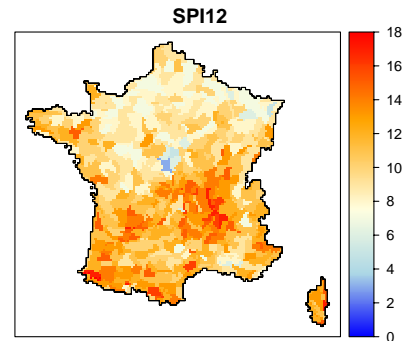

SSWI12

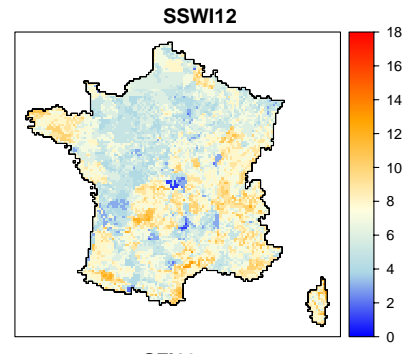

SFI12

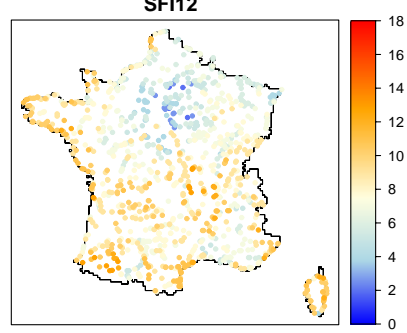

Fig. 6. Number of severe drought events, defined as events with severity above the $20 \%$ threshold. From left to right, time scales of 3 , 6 , and 12 months. From top to bottom, different indices: SPI, SSWI and SFI. Note the different colour scales for each time scale. The light yellow colour has been attributed to 30,15 and 7.5 for time scales of 3,6 and 12 months.

less events than the rest of the country at the 12-month time scale. Regional specificities clearly appear with SSWI and SFI as a result of the variability in soil properties and/or geological characteristics shown in Fig. 1. The general pattern that can be identified on SSWI maps is a larger number of events in areas with sandy soils with a low percentage of clay. In such areas, drainage processes are very fast and soil moisture evolution thus follows that of precipitation with a reduced buffering effect. There are clearly exceptions to this pattern, and differences resulting from different vegetation cover over similarly sandy soils can be spotted: Sologne area (center), with cultures and broadleaf forest and Landes area (south-west), with coniferous forest (see Habets et al., 2008, for a map of vegetation types over France). A more detailed analysis would be needed to connect those soil moisture patterns with soil and vegetation characteristics. The long memory of streamflow to meteorological conditions in catchments with a high permeability and large aquifers like the Seine basin (north of France) is shown through a very low number of hydrological drought events compared to other regions. This regional feature of drought event frequency matches quite well with specific clusters in natural flow regime classifications based on monthly runoff (Sauquet et al., 2008) or a range of hydrological indices (Snelder et al., 2009).

\subsection{Timing}

Figure 7 provides an indication of the timing of drought events by identifying the season when the highest number of events start to develop. It also shows if this number is significantly higher - at a 95\% confidence level - than the 1 in 4 probability, which represents a random occurrence of the starting time of the events throughout the year. The statistical test uses the Wilson confidence interval for binomial proportion as recommended by Brown et al. (2001). Such an approach thus hides situations when there is more than one season when the number is significantly higher than expected by chance.

Meteorological drought events appear to occur randomly throughout the year with 3-month and 6-month time scales, but at the 12-month scale, some areas show a statistically high number of events starting in winter in the north-west of the country, and in autumn in the south-east.

3-month soil moisture droughts tend to start in spring over the major part of the country, and in winter in the northeastern mountain ranges (Vosges and Jura). At the 6-month time scale, a significantly high proportion of events starts in autumn in the western part of the country and thus corresponds to summer soil moisture deficits. An interesting 

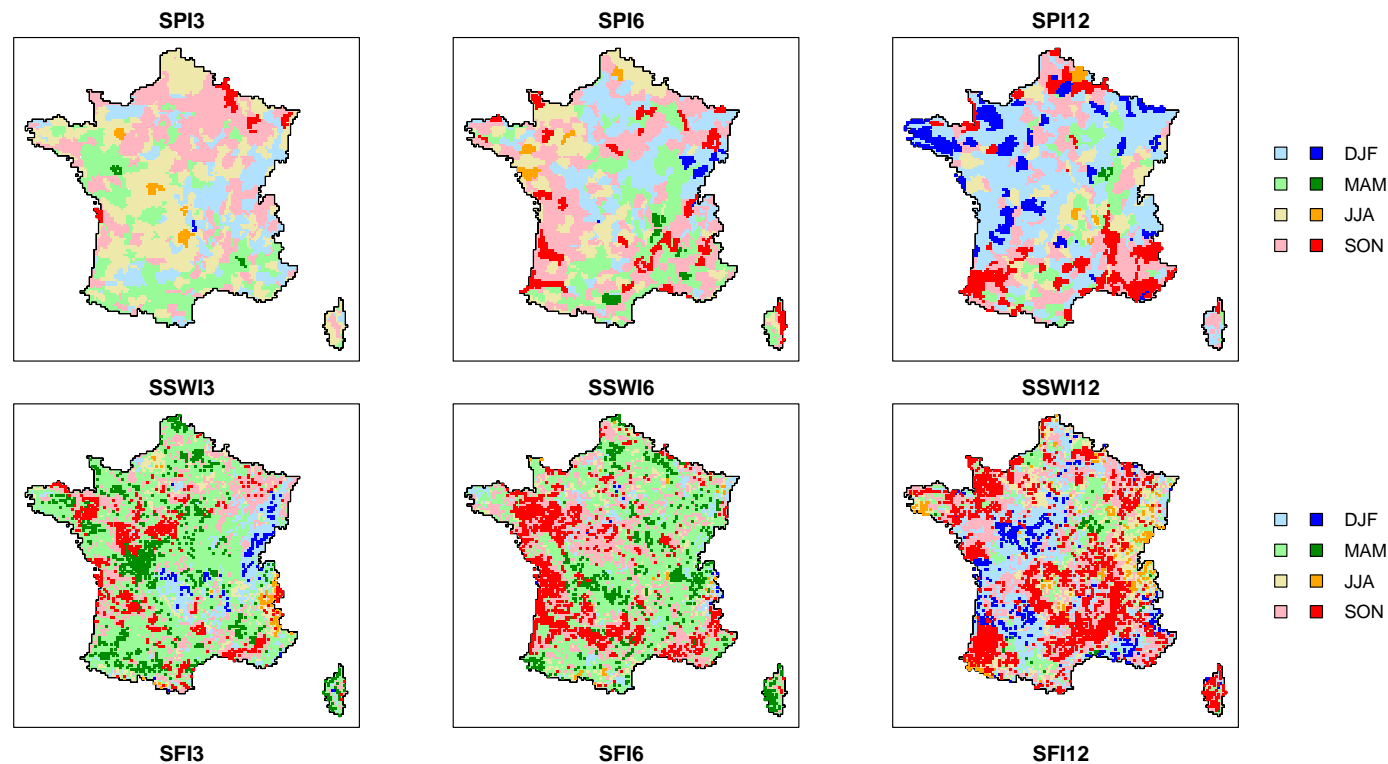

$\square \quad \square \quad$ MAM

$\square \quad$ JJA

$\square \quad$ SON
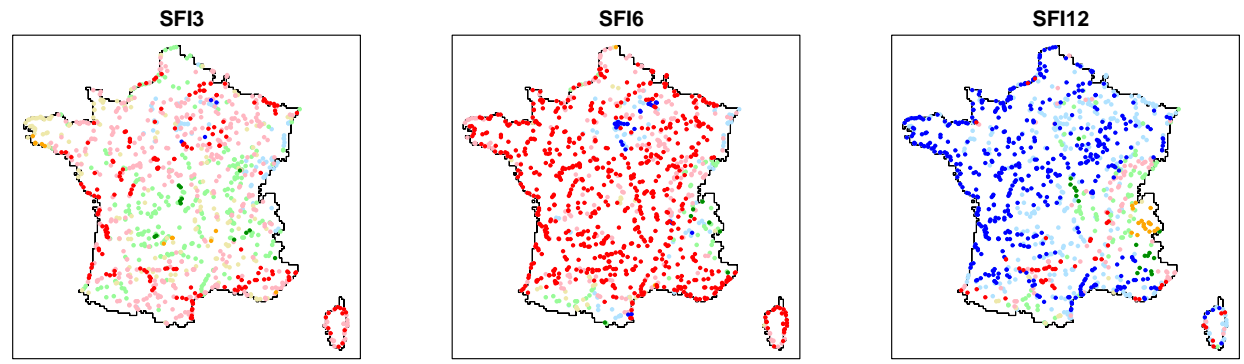

$\begin{array}{lll}0 & - & \text { DJF } \\ 0 & 0 & \text { MAM } \\ 0 & \bigcirc & \text { JJA } \\ 0 & 0 & \text { SON }\end{array}$

Fig. 7. Most frequent starting season for severe drought events, defined as events with severity above the $20 \%$ threshold. From left to right, time scales of 3, 6, and 12 months. From top to bottom, different indices: SPI, SSWI and SFI. Vivid colors indicate cells/stations where the proportion of events starting in the season considered is significantly higher than the 1 in 4 probability. See text for details.

feature is the apparent lack of 6-month agricultural droughts starting in Winter or Summer, suggesting the existence of two seasonal modes for this type of droughts. The distribution of the most frequent starting season is much more divided among the four seasons at the 12-month time scale, but with significant proportions only for autumn in regions like the Landes area (south-west), the Rhône valley, the Cevennes area and the Cotentin peninsula (north-west).

3-month streamflow droughts show a significantly high proportion in autumn in some parts of the Seine Basin, the coastal Mediterranean and Atlantic catchments and the downstream Garonne river. The major part of the country with the exception of the Alps and Pyrenees mountain ranges where snow melting processes are important - show a significantly high proportion of drought events starting in autumn at the 6-month time scale, that is deficits starting over the extended summer season. The picture is quite different at the 12-month time scale: a large part of the country show a significantly high proportion of streamflow droughts starting in winter. One interesting feature is the statistical significance of the occurrence of summer-starting events in the northern Alps, which shows that the influence of snowmelt deficits extends over a one-year time scale.

\subsection{Mean duration}

Figure 8 plots the mean duration of severe drought events over France and has to be related to the number of events shown in Fig. 6. Both characteristics are closely linked as the underlying variable is highly auto-correlated and follows a centered normal distribution, generating a negative relationship between duration and frequency of peak-underthreshold periods.

The spatial variability of the duration of meteorological droughts appears to be limited compared to that of agricultural and hydrological droughts, with the north of the country showing slightly longer events of precipitation deficit than the south. Local discrepancies that can be observed result from the low number of events used for computing the mean duration (see Fig. 6).

At all time scales, the mean duration of soil moisture droughts appears to be longer than that of precipitation droughts, due to the buffering effect of the soil mentioned earlier. The north of the country shows durations longer than three times the time scale considered.

The main feature shown by hydrological droughts is the large values of mean duration within the Seine basin due to 


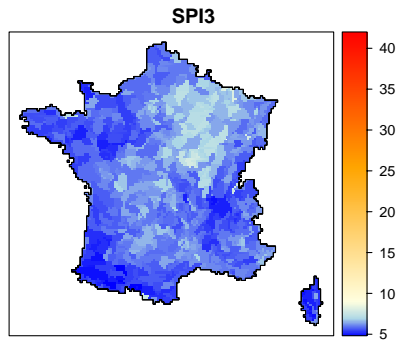

SSWI3
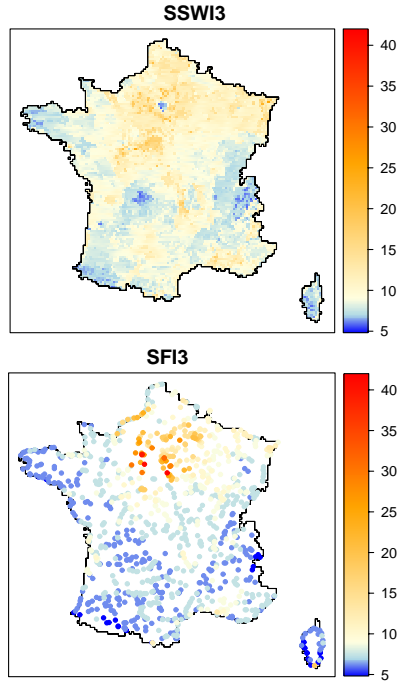

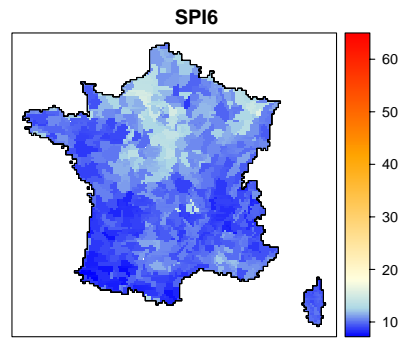

SSWI6
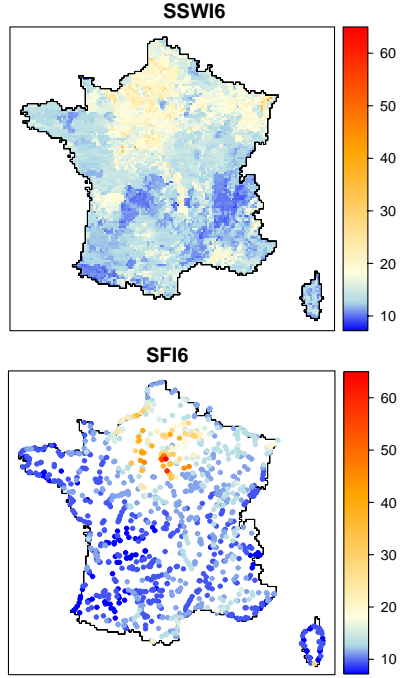

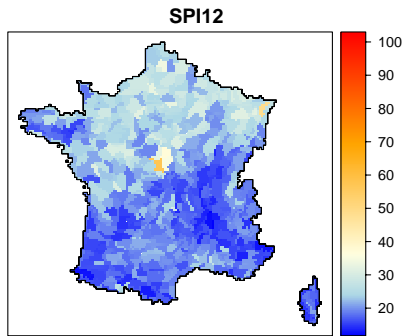

SSWI12
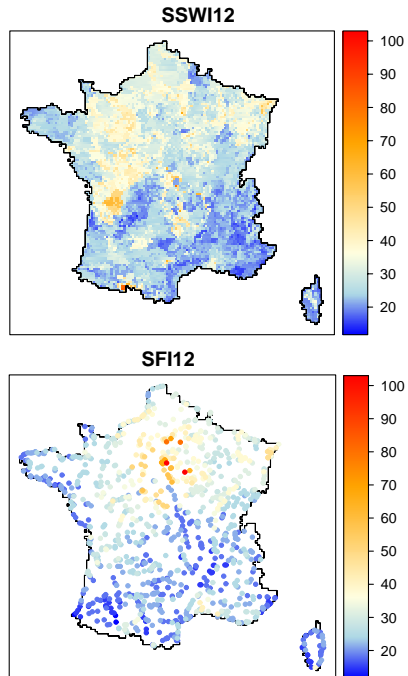

Fig. 8. Mean duration (in months) of severe drought events, defined as events with severity above the $20 \%$ threshold. From left to right, time scales of 3, 6, and 12 months. From top to bottom, different indices: SPI, SSWI and SFI. Note the different colour scales for each time scale. The light yellow colour has been attributed to three times the time scale considered.

the presence of vast aquifers. The remainder of the country tends to show shorter mean duration than for agricultural droughts.

\subsection{Mean magnitude}

Figure 9 plots the mean magnitude of severe drought events, with the same colour scale for all variable/time scale combinations. The magnitude integrates both the severity and the duration of the event considered and thus summarizes its potential impact. Figure 9 first shows an increase in mean magnitude with the time scale, as a consequence of the increase in mean duration shown in Fig. 8.

No clear regional pattern emerges for 3-month and 6month meteorological droughts, but 12-month droughts appear to be of higher magnitude in the northern half of the country, once again due to the longer mean duration shown in Fig. 8.

The magnitude pattern of both soil moisture and streamflow droughts is also closely linked to that of their mean duration. This link results from the quasi-linear relationship between duration and magnitude when severe events are considered (see McKee et al., 1993).

\section{National-scale drought characteristics}

This section attempts to provide a national-scale view of droughts by identifying and comparing severe drought events that occurred during the 1958-2008 period. Only gridded drought indices (SPI and SSWI) that allow to take account of the areal dimension of the event are here considered. At the scales of 3,6 , and 12 months, a number of, respectively 77 , 65 and 55 meteorological events have been identified (77, 66 and 51 agricultural events).

\subsection{Inter-comparison of events}

Spatio-temporal event summary statistics described in Sect. 2.3.2 are compared in Fig. 10 at different time scales. It shows relationships between mean area, mean duration and total magnitude for all drought events identified during the 50 -yr period. Meteorological and agricultural drought events are examined at the time scales of 3, 6 and 12 months. The general feature in Fig. 10 is an increase (resp. decrease) in drought mean duration (resp. mean area) with increasing time scale, due to the intrinsic properties of the standardized indices. Agricultural droughts also tend to last longer than meteorological droughts, which has been already noted at the local scale (see Fig. 8). 

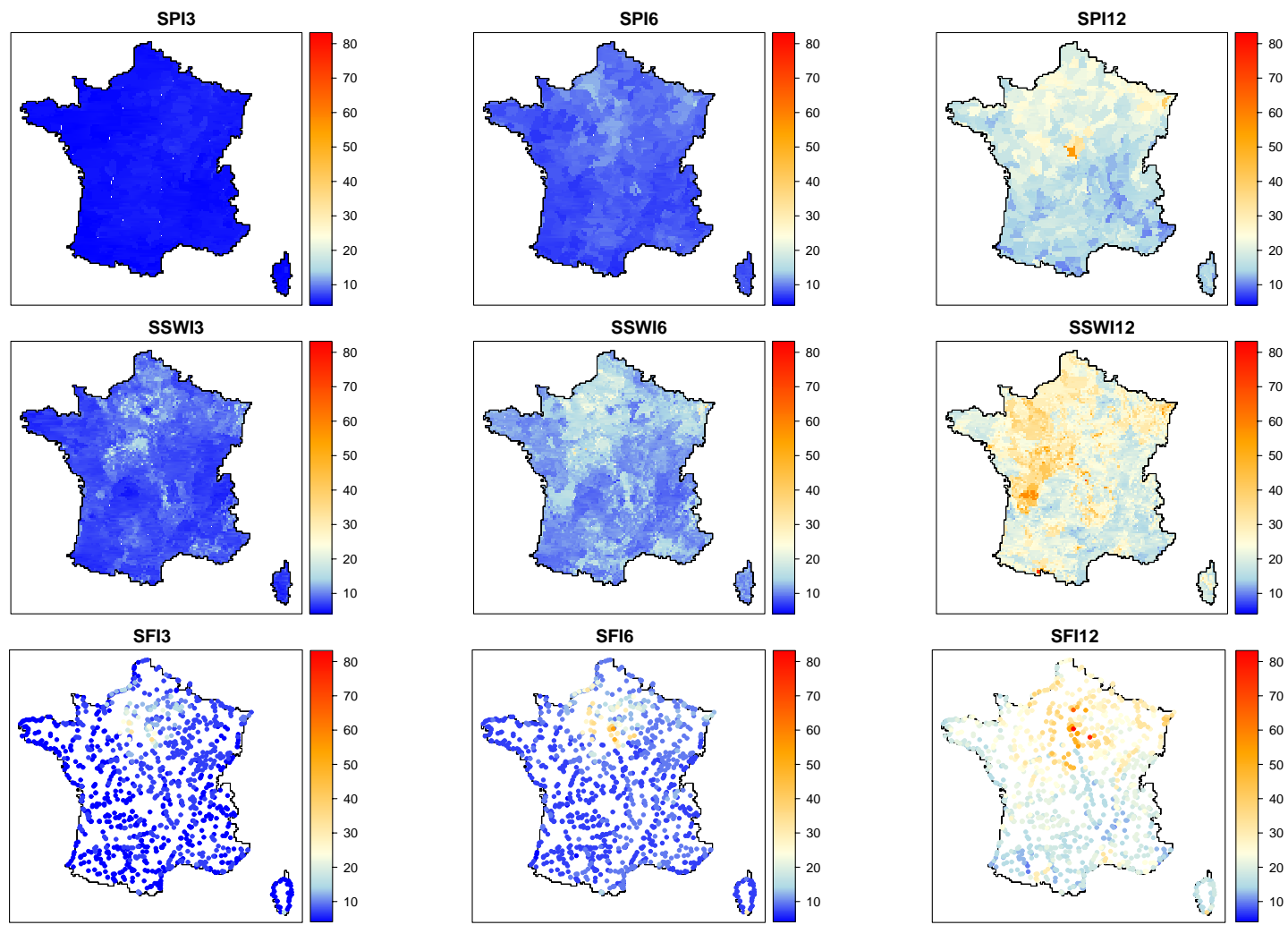

Fig. 9. Mean magnitude (in months) of severe drought events, defined as events with severity above the $20 \%$ threshold. From left to right, time scales of 3, 6, and 12 months. From top to bottom, different indices: SPI, SSWI and SFI. The colour scale is the same throughout the plots, with the light yellow color attributed to a value of 24 months.

Figure 10 also highlights 6 major events for which summary characteristics can be tracked across time scales and drought types. The 1976 drought (in red) described in Sect. 4 appears to be exceptional at short time scales in terms of precipitation deficits, but less exceptional when considering soil moisture deficits and/or long time scales. Similar observations can be made for the Autumn 1978 drought, in purple (see Bellocq, 1979, for a meteorological account) and for the Autumn 1985 drought, in brown (Larivière, 1985).

The 2003 drought (in orange) do not appear to be exceptional in terms of precipitation deficits, but reaches the second or even first place in terms of magnitude of soil moisture deficits over the 50-yr period. This can be explained by the remarkable duration of this sustained agricultural event, which includes three or four peaks from 2003 to 2006/2008, visible on Fig. 3 at the 12-month time scale. A similar feature can be noted for the 1971-1972 winter drought event which incorporates at long time scales the Winter/Spring deficits of previous and following years. Such observations highlight the significance of two parameters in the spatio-temporal drought identification algorithm: the drought threshold level, but also the minimum overlapping area between two time steps.
Finally, the 1989-1990 drought appears to be the most severe event over the last $50 \mathrm{yrs}$ in terms of soil moisture deficits and in terms of long time-scale precipitation deficits. Its duration is particularly noteworthy compared to other events, with a dry phase between July 1989 to January 1990 following an already very dry 1988-1989 Winter (Mérillon and Chaperon, 1990) and preceding other deficit periods in 1990 (see Fig. 3).

\subsection{Identification of benchmark events}

The Severity-Area-Time Scale analysis (see Sect. 2.3.2) of the events described above led to the building of curves showing the highest mean severity over a given area registered during each event, and for time scales varying from 1 month to 24 months. For each time scale, the envelope curve of all single-event curves was drawn and the most severe events that composed this curve were identified. Figure 11 shows the output of this process and identifies the events during which the highest mean severity over a given area - within the 50-yr period - was reached, at all time scales.

The five events described in the previous section can be recognized in Fig. 11 with colours similar as in Fig. 10: the 1976 drought appears to be the prevalent benchmark 

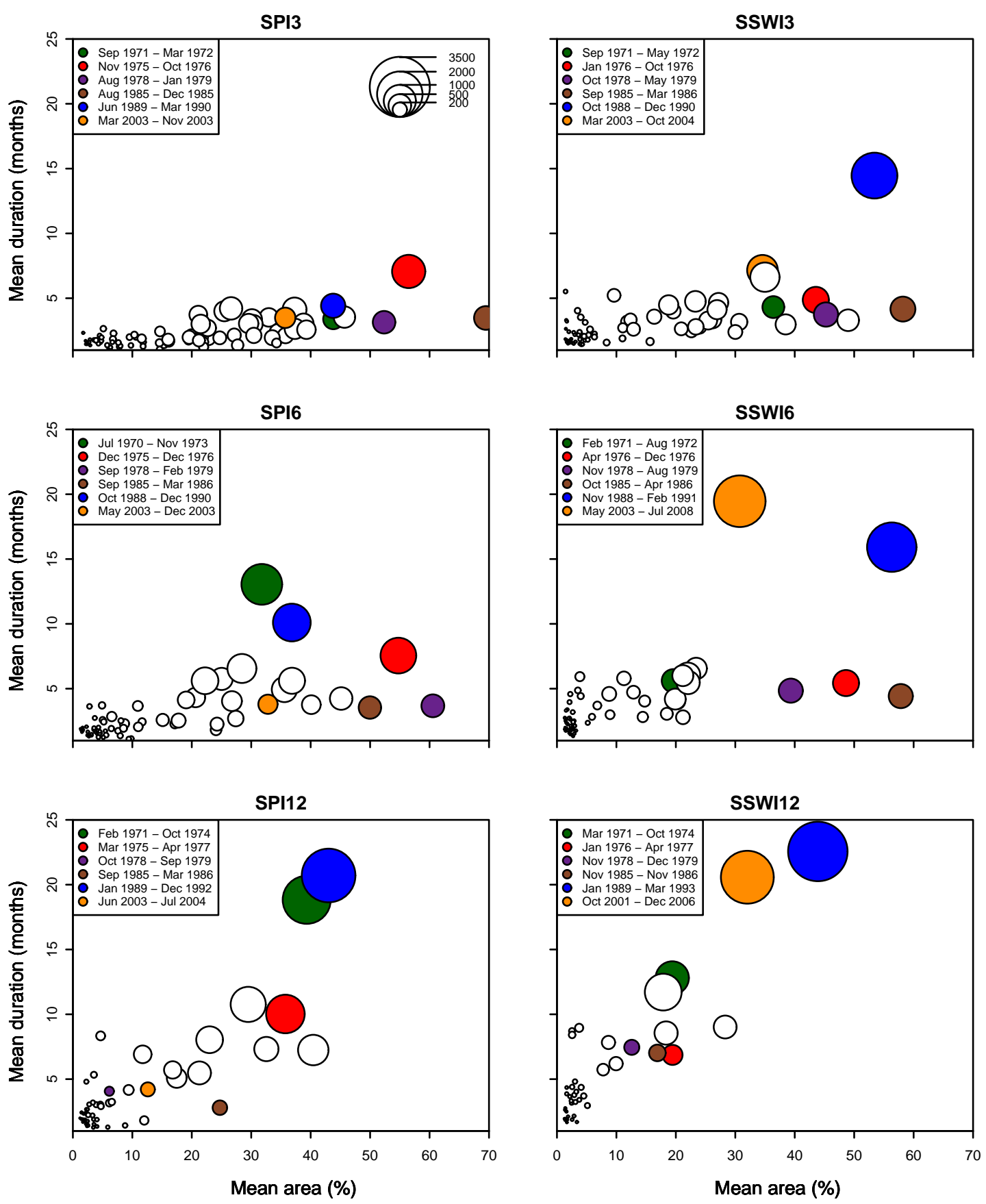

Fig. 10. Relation between mean area, mean duration and total magnitude for all drought events identified with SPI (left column) and SSWI (right column), with time scales of 3, 6 and 12 months (from top to bottom) and a threshold of 20\%. Disk area is proportional to total magnitude. The magnitude scale, in month by percent of France area, is given in top left plot. Six major drought events are identified with colours consistent throughout the figure.

meteorological event for time scales from 3 to 15 months, while the 1989-1990 drought takes over for longer time scales as well as for time scales higher than 6 months at the agricultural level. This plot also points out the short and intense Autumn droughts of 1978 and 1985, as well as the 1972 drought during which exceptional soil moisture deficits were recorded in the Rhine valley (see Bréda and Badeau, 2008, for an impact analysis on forests). The 2003 drought rarely appears as a benchmark event.

Two additional events complete the panel of benchmark events for small time scales: first, March 1961, when virtually no rainfall was observed on several French 


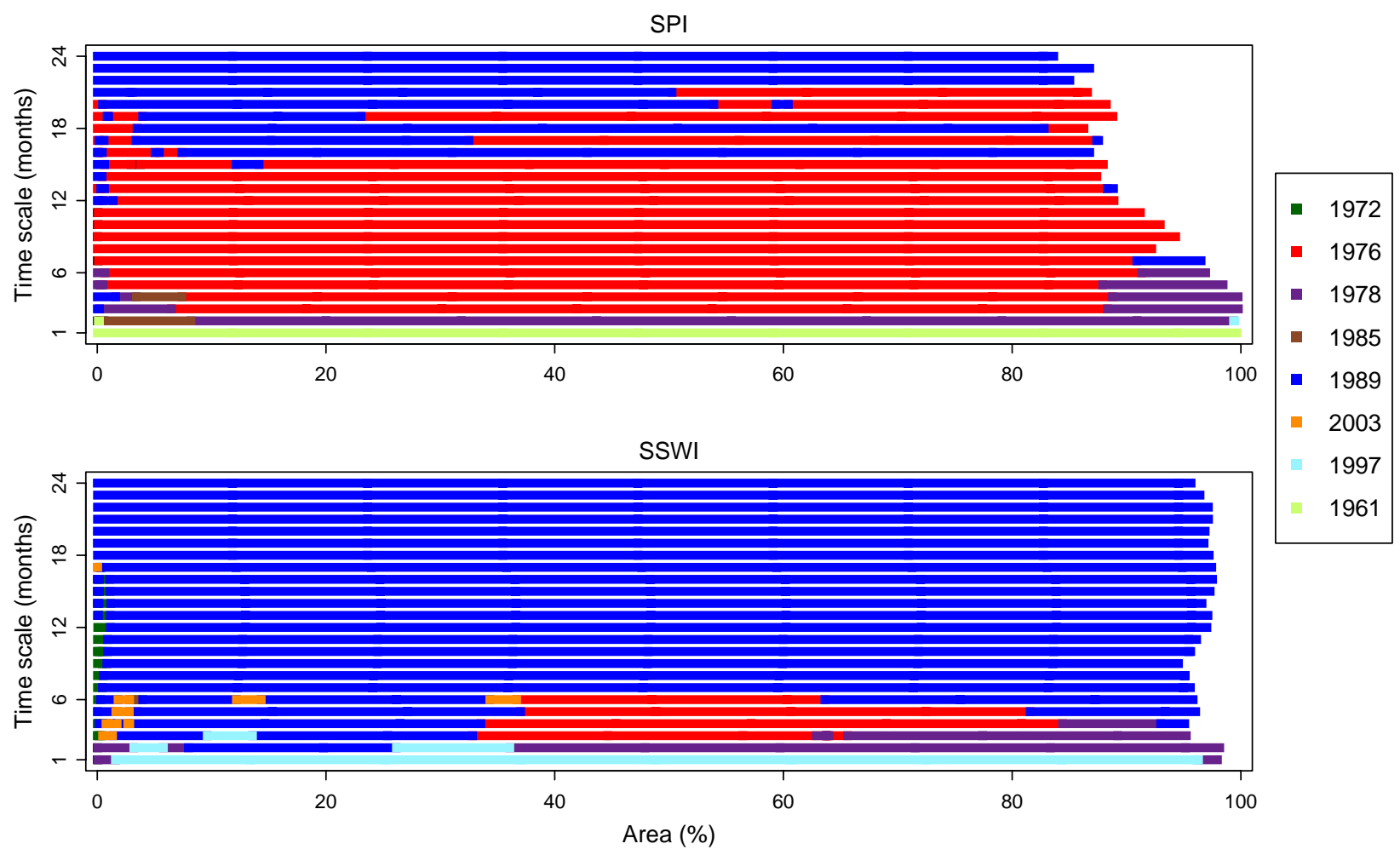

Fig. 11. Identification of events with the highest mean severity over a given surface area, for time scales from 1 to 24 months. Top: meteorological droughts; bottom: agricultural droughts. Events are here identified across time scales by the single year when the maximum 1-month precipitation deficit was reached.

regions (Direction de la Météorologie Nationale, 1961), and that thus constitutes the benchmark event at 1-month scale for meteorological drought. Second, April 1997, when soil moisture values were very low as a consequence of two very dry months during the period of recharge (Météo-France, 1997), and that is the benchmark event at 1-month scale for agricultural drought.

\section{Discussion}

\subsection{Uncertainties}

This section aims at assessing the different sources of uncertainties in the modelling suite that may impact the results of this drought reanalysis.

\subsubsection{Off-line simulation}

The drought reanalysis has been performed on the basis of an off-line hydrological simulation, like the most recent highresolution retrospective drought analyses (e.g., Andreadis et al., 2005, for the US). Consequently, it does not take account of soil-atmosphere feedbacks that can be significant during dry periods, especially in the Mediterranean area (see, e.g., Vautard et al., 2007). Computed soil moisture values during such periods of retroaction may thus be underestimated. However, the comparison made by Rüdiger et al. (2009) between SWI values from Isba and in situ soil moisture observations at the SMOSREX experimental site (SouthWest France, de Rosnay et al., 2006) showed that this underestimation remained limited even during the very hot summer of 2003.

\subsubsection{Land use change}

Another characteristic of this simulation - shared to the authors' knowledge by all other drought reconstructing studies using Land Surface Models (LSMs) - is that no land-use change was considered during the modelled period. Over the last $50 \mathrm{yrs}$, the effects of land-use change in France on drought reconstruction should however be limited to smallscale zones like recently urbanized areas and should not have a significant impact on the national-scale spatio-temporal patterns of droughts.

\subsubsection{LSM configuration}

A potentially significant source of uncertainty may be found in the configuration of the LSM. Indeed, the land-surface simulation has been here performed with a single model 
(Isba) and results are thus subject to the uncertainty in soil moisture state, that has been shown to be a highly modeldependent quantity by Koster et al. (2009). The impact of LSM configuration on soil moisture drought reconstruction has been tested by Wang et al. (2009) over the continental United States. They reconstructed historical droughts by forcing 6 different LSMs by the same meteorological dataset and found substantial differences in model-derived soil moisture values, mainly due to different water-holding capacities among the different LSMs. However, they found that the standardization of results - in their case in terms of percentiles of model climatology - leads to comparable and plausible spatio-temporal patterns of soil moisture droughts. The intercomparison made by Wang et al. (2009) as well as the good spatio-temporal agreement with hydrological droughts identified by Hannaford et al. (2009) from observed streamflow thus suggests a relatively low impact of model configuration uncertainty on the present 50-yr drought reanalysis over France.

\subsubsection{Validation period}

Although the Safran atmospheric reanalysis has been thoroughly validated over the 50-yr period, the whole SIM suite has only been compared to observed hydrological data over the period 1995-2005 by Habets et al. (2008). Some uncertainties thus remain on how well the relevant hydrological variables (soil moisture and streamflow) have been simulated over the remaining of the period. A comprehensive validation over the whole period would however prove very difficult because of the lack of soil moisture data before the last two decades or so, and because of the very small extent of the hydrometric network density before the 1970s.

\subsubsection{Reservoirs}

A number of large reservoirs are located in various areas of France, mainly in the Alps and the Pyrenees. These reservoirs have a significant impact on river flow regimes and are not explicitly modelled within the SIM suite. All related operations, like reservoir filling during the snowmelt season and low-flow sustaining schemes for irrigation and water supply, may contribute to increase the discrepancies between observed and modelled streamflow, as noted by Habets et al. (2008). Moreover, the number of reservoirs and their management rules did vary over the 50-yr period, which leads to non-stationary observed streamflow regimes. As a consequence, SFI data may not completely represent the actually observed streamflow drought conditions, but as noted above, there is a nevertheless a good general agreement with indices derived from observed streamflow series at a rather large spatial scale (Hannaford et al., 2009; Lloyd-Hughes et al., 2009b).

\subsection{Drought detection parameters}

This section gathers elements of discussion on the different parameters (thresholds) of the drought detection algorithm developed in this study (See Sect. 2.3).

The first parameter is the local-scale threshold on drought index values used to distinguish severe drought events. The value adopted in this study corresponds to a commonly used $20 \%$ probability, but it should really be based on thresholds relevant for operational water management and that would integrate the vulnerability of the hydrosystem considered.

Two further area thresholds are used in the spatio-temporal identification of drought events. The first one is the minimum contiguous area affected by drought, and the second one is the minimum overlapping area between two time steps. These thresholds have been given rather arbitrary values here in order to provide homogeneous results at the national scale. Consequently, they are too large for small-scale assessments relevant for operational water resource management, and the first one at least should ideally be based on a percent area of the catchment/water resource zone considered. Additionally, the independence of spatio-temporal events should ideally be based on considerations about the independence of atmospheric causes, that would for example lead to identify several distinct phases within a single event.

\subsection{Drought seasonality}

Section 5.2 provided preliminary considerations on agricultural and hydrological drought seasonality. Such considerations give insights on features worthwhile investigating further for drought preparedness purposes. The identification of seasonality patterns in hydrological droughts would prove particularly useful for water resources management. The striking correspondence between timing results on 6-months hydrological droughts and the flow regime classification of Snelder et al. (2009) suggests, for example, that relationships with flow regime descriptors (see, e.g., Olden and Poff, 2003) could be explored. These seasonality patterns are furthermore linked to the local-scale threshold discussed above and a sensitivity analysis to this parameter would help to assess the robustness of the conclusions.

\section{Conclusions}

This paper describes a 50-yr retrospective analysis of droughts in France by considering different levels of the hydrological cycle (precipitation, soil moisture and streamflow) and different time scales (1 to 24 months). The motivation for this multilevel and multiscale approach originates from the diversity of variables and time scales relevant in the variety of socio-economic sectors potentially affected by a drought. This study applied standardized indices to precipitation, soil moisture and streamflow computed by the SafranIsba-Modcou hydrometeorological suite. Such an approach 
provides a consistent assessment of drought conditions both spatially and throughout the land surface hydrological cycle.

This 50-yr drought reanalysis allowed the identification of dry periods experienced in France and the description through the examination of two specific events - of the way a drought propagates through the hydrological cycle. Modelling the complete surface water and energy budgets allowed for example to describe agricultural drought events like 2003 which were driven not only by precipitation deficits by also by positive temperature anomalies. A local-scale analysis of drought events identified regional specificities of drought characteristics: frequency, duration, timing and magnitude. Frequency and duration results for example show that water managers should prepare to face diverse physical drought patterns across the country, and that these patterns are closely linked with the climate, soil and vegetation of the catchment considered. They are moreover highly dependent on both the time scale and the variable considered. Characteristics of individual spatio-temporal drought events were then compared at the national scale in order to identify benchmark events among those that occurred during the last $50 \mathrm{yrs}$. The analysis of benchmark events has been here performed at the national scale, but it would be relevant to run it at the scale of each catchment/water resource zone. This would provide water managers with the actual worst-case events of the last 50 -year over their specific zone of interest. The ranking of drought events, either from summary statistics or SeverityArea-Time scale curves, is also highly dependent on both the time scale and the level of the hydrological cycle considered.

The drought characteristics identified during the 19582008 period will serve as a reference for the assessment of the impact of climate change on droughts in France. Further work on the CLIMSEC project will make use of Isba-Modcou hydrological simulations forced by downscaled climate projections for the 21 st century in order to evaluate the potential changes in drought characteristics through techniques recently applied to UK meteorological droughts (Vidal and Wade, 2009). The land-surface modelling approach adopted here will allow the description of changes in drought characteristics driven by changes not only in precipitation but also in temperature.

The set of drought indices developed in this study constitutes a versatile tool that can be used in an operational context for drought monitoring. This set of indices naturally extends the widely used - and recently recommended by the World Meteorological Organization - SPI to other levels of the hydrological cycle (soil moisture, streamflow). The use of these indices by water managers would first require to find for their water resource systems the most appropriate combination between the level of the hydrological cycle (precipitation, soil moisture, streamflow) and the time scale, based on the comparison of their expertise and experience of past events and retrospective results from the set of indices. Such an experimentation is currently under way with several water agencies across the country. In this context, it would be relevant to also compute both SPI and SSWI at the catchment scale for a direct comparison with SFI. Near real-time computation of the selected index could thus help water managers to evaluate the present drought situation with respect to the 50-yr historical period.

This set of drought indices will complete the ensemble of tools currently used by Météo-France for water resources monitoring (Soubeyroux et al., 2008; Blanchard et al. , 2007) or hydrological seasonal forecasting (Céron et al., 2010). It also opens some perspectives for multilevel and multiscale drought monitoring at the broader European scale.

Acknowledgements. This work was carried out within the CLIMSEC project (Impact of climate change on drought and soil moisture in France) funded by Fondation MAIF and Météo-France. The authors would like to thank the four anonymous referees for their helpful comments and suggestions that greatly improved the original manuscript.

Edited by: F. Pappenberger

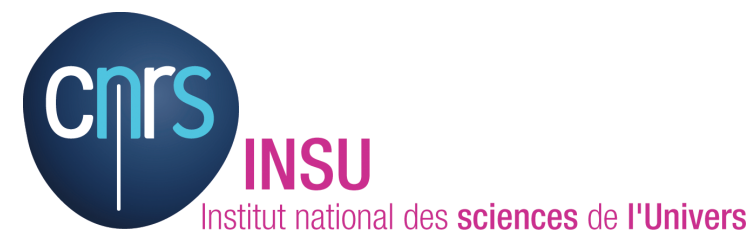

The publication of this article is financed by CNRS-INSU.

\section{References}

Albergel, C., Rdiger, C., Pellarin, T., Calvet, J.-C., Fritz, N., Froissard, F., Suquia, D., Petitpa, A., Piguet, B., and Martin, E.: From near-surface to root-zone soil moisture using an exponential filter: an assessment of the method based on in-situ observations and model simulations, Hydrol. Earth Syst. Sci., 12, 1323-1337, 2008 ,

http://www.hydrol-earth-syst-sci.net/12/1323/2008/.

Andreadis, K. M., Clark, E. A., Wood, A. W., Hamlet, A. F., and Lettenmaier, D. P.: Twentieth-century drought in the conterminous United States, J. Hydrometeorol., 6, 985-1001, doi:10.1175/JHM450.1, 2005.

Baghdadi, N., Aubert, M., Cerdan, O., Franchistéguy, L., Viel, C., Martin, E., Zribi, M., and Desprats, J.-F.: Operational mapping of soil moisture using synthetic aperture radar data: application to the Touch basin (France), Sensors, 7, 2458-2483, doi:10.3390/s7102458, 2007.

Bellocq, A.: La sécheresse de l'automne 1978 en France - Aspect pluviométrique (Translation: The Autumn 1978 drought in France - Precipitation features), La Météorologie, 16, 229-256, 1979 (in French).

Besleaga, N.: La sécheresse en France: 1976-1990 (Translation: Drought in France: 1976-1990), no. 1 in Phénomènes remarquables, Direction de la Météorologie Nationale, Service Central Exploitation Météorologique, 1992 (in French). 
Bessemoulin, P., Bourdette, N., Courtier, P., and Manach, J.: La canicule d'août 2003 en France et en Europe (Translation: The August 2003 heat wave in France and Europe), La Météorologie, 46, 25-33, 2004 (in French).

Blanchard, M., Franchistéguy, L., Habets, F., Martin, E., and Noilhan, J.: Typology of droughts over France and tools for estimation of water resources used at Météo-France, Rev. Fr. Géotech., 120-121, 11-20, 2007.

Bordi, I., Fraedrich, K., Gerstengarbe, F.-W., Werner, P. C., and Sutera, A.: Potential predictability of dry and wet periods: Sicily and Elbe-Basin (Germany), Theor. Appl. Climatol., 77, 125-138, doi:10.1007/s00704-003-0029-0, 2004.

Bréda, N. and Badeau, V.: Forest tree responses to extreme drought and some biotic events: Towards a selection according to hazard tolerance?, C. R. Géosci., 340, 651-662, doi:10.1016/j.crte.2008.08.003, 2008.

Bremond, R.: L'incidence du déficit de pluie sur l'écoulement des rivières (Translation: Effect of precipitation deficits on river flows), Ponts Chauss. Mag., 12, 49-58, 1976 (in French).

Briffa, K. R., Jones, P. D., and Hulme, M.: Summer moisture variability across Europe, 1892-1991 - An analysis based on the Palmer Drought Severity Index, Int. J. Climatol., 14, 475-506, doi:10.1002/joc.3370140502, 1994.

Brochet, P.: Aspects climatiques de la sécheresse 1976 (Translation: Climatic aspects of the 1976 drought), La Météorologie, 7, 81103, 1976 (in French).

Brown, L. D., Cai, T. T., and DasGupta, A.: Interval estimation for a binomial proportion, Stat. Sci., 16, 101-133, doi:10.1214/ss/1009213286, 2001.

Buisson, G.: Évaluation des coûts des sécheresses au niveau national (Translation: National-scale cost assessment of droughts), Lettre Évaluation du Ministère de l'Écologie, de l'Énergie, du Développement Durable et de l'Aménagement du Territoire, 8, 3-4, http://www.ecologie.gouv.fr/IMG/pdf/LE08-2007.pdf, last access: 5 March 2010, 2007 (in French).

Choisnel, E.: Le bilan hydrique et le bilan d'énergie du sol (Tranlation: The soil water and energy budgets), La Météorologie, 11, 103-159, 1977 (in French).

Céron, J.-P., Tanguy, G., Franchistéguy, L., Martin, E., Regimbeau, F., and Vidal, J.-P.: Hydrological seasonal forecast over France: feasibility and prospects, Atmos. Sci. Lett., doi:10.1002/as1.256, in press, 2010.

de Rosnay, P., Calvet, J.-C., Kerr, Y., Wigneron, J.-P., Lemaitre, F., Escorihuela, M. J., Sabater, J. M., Saleh, K., Barrié, J., Bouhours, G., Coret, L., Cherel, G., Dedieu, G., Durbe, R., Fritz, N. E. D., Froissard, F., Hoedjes, J., Kruszewski, A., Lavenu, F., Suquia, D., and Waldteufel, P.: SMOSREX: A long term field campaign experiment for soil moisture and land surface processes remote sensing, Remote Sens. Environ., 102, 377-389, doi:10.1016/j.rse.2006.02.021, 2006.

Direction de la Météorologie Nationale: Résumé mensuel du temps en France - Mars 1961 (Translation: Monthly weather summary in France - March 1961), Tech. rep., Direction de la Météorologie Nationale, 1961 (in French).

D'Odorico, P., Ridolfi, L., Porporato, A., and Rodriguez-Iturbe, I.: Preferential states of seasonal soil moisture: The impact of climate fluctuations, Water Res. Res., 36, 2209-2219, doi:10.1029/2000WR900103, 2000.
Dutra, E., Viterbo, P., and Miranda, P. M. A.: ERA40 reanalysis hydrological applications in the characterization of regional drought, Geophys. Res. Lett., 35, L19402, doi:10.1029/2008GL035381, 2008.

European Commission: Water Scarcity and Droughts: InDepth Assessment, Interim Report 2, European Commission, http://ec.europa.eu/environment/water/quantity/pdf/comm droughts/2nd_int_report.pdf, last access: 5 March 2010, 2007.

Gandin, L. V.: Objective analysis of meteorological fields, Israel Program for Scientific Translations, Jerusalem, Israel, 242 pp., 1965.

Guttman, N. B.: Accepting the Standardized Precipitation Index: A calculation algorithm, J. Am. Water Res. Assoc., 35, 311-322, doi:10.1111/j.1752-1688.1999.tb03592.x, 1999.

Habets, F., Noilhan, J., Golaz, C., Goutorbe, J.-P., Lacarrère, P., Leblois, E., Ledoux, E., Martin, E., Ottlé, C., and Vidal-Madjar, D.: The ISBA surface scheme in a macroscale hydrological model applied to the Hapex-Mobilhy area - Part II: Simulation of streamflows and annual water budget, J. Hydrol., 217, 97-118, doi:10.1016/S0022-1694(99)00020-7, 1999.

Habets, F., Boone, A., Champeaux, J.-L., Etchevers, P., Franchistéguy, L., Leblois, E., Ledoux, E., Le Moigne, P., Martin, E., Morel, S., Noilhan, J., Quintana Seguí, P., Rousset-Regimbeau, F., and Viennot, P.: The SAFRAN-ISBA-MODCOU hydrometeorological model applied over France, J. Geophys. Res., 113, D06113, doi:10.1029/2007JDOO8548, 2008.

Hannaford, J., Lloyd-Hughes, B. J., Keef, C., Parry, S., and Prudhomme, C. P.: Examining the large-scale spatial coherence of European drought using regional indicators of rainfall and streamflow deficit, Hydrol. Proces., submitted, 2009.

Hisdal, H. and Tallaksen, L. M.: Estimation of regional meteorological and hydrological drought characteristics: a case study for Denmark, J. Hydrol., 281, 230-247, doi:10.1016/S00221694(03)00233-6, 2003.

Hisdal, H., Tallaksen, L. M., Clausen, B., Peters, E., and Gustard, A.: Hydrological drought characteristics, in: Hydrological drought - Processes and estimation methods for streamflow and groundwater, vol. 48 of Developments in Water Science, chapter 5, Elsevier, Amsterdam, The Netherlands, 139-198, 2004.

Hosking, J. R. M.: $L$-moments: analysis and estimation of distributions using linear combinations of order statistics, J. R. Stat. Soc. B, 52, 105-124, 1990.

Koster, R. D., Guo, Z., Dirmeyer, P. A., Yang, R., Mitchell, K., and Puma, M. J.: On the nature of soil moisture in land surface models, J. Clim., 22, 4322-4335, doi:10.1175/2009JCLI2832.1, 2009.

Lana, X., Serra, C., and Burgueño, A.: Patterns of monthly rainfall shortage and excess in terms of the standardized precipitation index for Catalonia (NE Spain), Int. J. Climatol., 21, 1669-1691, doi:10.1002/joc.697, 2001.

Larivière, G.: La sécheresse en France en septembre 1985 (Translation: The drought in France in September 1985), La Météorologie, 10, p. 54, 1985 (in French).

Le Roy Ladurie, E.: Histoire humaine et comparée du climat, vol. III Le réchauffement de 1960 à nos jours, Fayard, Paris, 461 pp., 2009.

Ledoux, E., Girard, G., De Marsily, G., and Deschenes, J.: Spatially distributed modeling: conceptual approach, coupling surface water and ground-water, in: Unsaturated flow hydrologic modeling: 
theory and practice, edited by: Morel-Saytoux, H. J., vol. 275 of NATO ASI Series C, Kluwer, Norwell, Massachussets, 435-454, 1989.

Liang, X., Lettenmaier, D. P., Wood, E. F., and J., B. S.: A simple hydrologically based model of land-surface water and energy fluxes for general-circulation models, J. Geophys. Res., 99, 14415-14428, 1994.

Lloyd-Hughes, B. and Saunders, M. A.: A drought climatology for Europe, Int. J. Climatol., 22, 1571-1592, doi:10.1002/joc.846, 2002.

Lloyd-Hughes, B., Hannaford, J., Parry, S., Keef, C., Prudhomme, C., and Rees, G.: The spatial coherence of European droughts Stage 1: UK and European drought catalogues - Methodology, Science Report SC070079/SR1, Environment Agency, Bristol, UK, 2009a.

Lloyd-Hughes, B., Hannaford, J., Parry, S., Keef, C., Prudhomme, C., and Rees, H. G.: Drought catalogues for UK and Europe, Science Report SC070079/SR, Environment Agency, 2009b.

Loukas, A. and Vasiliades, L.: Probabilistic analysis of drought spatiotemporal characteristics in Thessaly region, Greece, Nat. Hazards Earth Syst. Sci., 4, 719-731, 2004,

http://www.nat-hazards-earth-syst-sci.net/4/719/2004/.

López-Moreno, J. I., Vicente-Serrano, S. M., Beguería, S., GarcíaRuiz, J. M., Portela, M. M., and Almeida, A. B.: Dam effects on droughts magnitude and duration in a transboundary basin: The Lower River Tagus, Spain and Portugal, Wat. Resour. Res., 45, W02405, doi:10.1029/2008WR007198, 2009.

Luterbacher, J., Dietrich, D., Xoplaki, E., Grosjean, M., and Wanner, H.: European seasonal and annual temperature variability, trends, and extremes since 1500, Science, 303, 1499-1503, doi:10.1126/science.1093877, 2004.

Masson, V., Champeaux, J.-L., Chauvin, F., Meriguet, C., and Lacaze, R.: A global database of land surface parameters at $1-\mathrm{km}$ resolution in meteorological and climate models, J. Clim., 16, 1261-1282, doi:10.1175/15200442(2003)16<1261:AGDOLS>2.0.CO;2, 2003.

Maurer, E. P., Wood, A. W., Adam, J. C., and Lettenmaier, D. P.: A long-term hydrologically based dataset of land surface fluxes and states for the conterminous United States, J. Clim., 15, 3237-3251, doi:10.1175/15200442(2002)015<3237:ALTHBD>2.0.CO;2, 2002.

McKee, T., Doesken, N., and Kleist, J.: The relationship of drought frequency and duration to time scales, in: Preprints of the 8th Conference on Applied Climatology, Anaheim, California, 179184, 1993.

McKee, T. B., Doesken, N. J., and Kleist, J.: Drought monitoring with multiple time scales, in: Preprints of the 9th Conference on Applied Climatology, Anaheim, California, 233-236, 1995.

Mo, K. C.: Model-based drought indices over the United States, J. Hydrometeorol., 9, 1212-1230, doi:10.1175/2008JHM1002.1, 2008.

Moreau, F.: Drought crisis management: Loire basin example, La Houille Blanche, 4, 70-76, doi:10.1051/lhb:200404010, 2004.

Mounier, J.: Aspects et fréquences de la sécheresse en Bretagne : essai de définition de la sécheresse en Europe océanique (Translation: Specificities and frequency of drought in Britanny: proposition for defining drought in the western coastal part of Europe), Rev. Géogr. Lyon, 52, 167-176, 1977 (in French).
Mérillon, Y. and Chaperon, P.: La sécheresse de 1989 (Translation: The 1989 drought), La Houille Blanche, 5, 325-339, 1990 (in French).

Météo-France: Bulletin Climatique - Avril 1997 (Translation: Climate bulletin, April 1997), Tech. rep., Météo-France, 12 pp., 1997 (in French).

Noilhan, J. and Lacarrère, P.: GCM grids evaporation from mesoscale modeling, J. Clim., 8, 206-223, doi:10.1175/15200442(1995)008<0206:GGSEFM>2.0.CO;2, 1995.

Noilhan, J. and Mahfouf, J.-F.: The ISBA land surface parameterisation scheme, Global Planet. Change, 13, 145-159, doi:10.1016/0921-8181(95)00043-7, 1996.

Olden, J. D. and Poff, N. L.: Redundancy and the choice of hydrologic indices for characterizing streamflow regimes, River Res. Appl., 19, 101-121, doi:10.1002/rra.700, 2003.

Palmer, W. C.: Meteorological Drought, Research paper 45, US Department of Commerce, US Weather Bureau, Office of Climatology, Washington, DC, http://lwf.ncdc.noaa.gov/oa/climate/ research/drought/palmer.pdf, last access: 5 March 2010, 1965.

Paris Anguela, T., Zribi, M., Hasenauer, S., Habets, F., and Loumagne, C.: Analysis of surface and root-zone soil moisture dynamics with ERS scatterometer and the hydrometeorological model SAFRAN-ISBA-MODCOU at Grand Morin watershed (France), Hydrol. Earth Syst. Sci., 12, 1415-1424, 2008, http://www.hydrol-earth-syst-sci.net/12/1415/2008/.

Piccarreta, M., Capolongo, D., and Boenzi, F.: Trend analysis of precipitation and drought in Basilicata from 1923 to 2000 within a southern Italy context, Int. J. Climatol., 24, 907-922, doi:10.1002/joc.1038, 2004.

Prudhomme, C. and Sauquet, E.: Modelling a Regional Drought Index in France, Euraqua report, $\mathrm{CEH}$ and Cemagref, Wallingford, UK and Lyon, France, http://nora.nerc.ac.uk/ 1366/1/EuraquaDroughtForecastingFinalReport.pdf, last access: 5 March 2010, 2007.

Quintana-Seguí, P., Le Moigne, P., Durand, Y., Martin, E., Habets, F., Baillon, M., Canellas, C., Franchistéguy, L., and Morel, S.: Analysis of near-surface atmospheric variables: Validation of the SAFRAN analysis over France, J. Appl. Meteor. Climatol., 47, 92-107, doi:10.1175/2007JAMC1636.1, 2008.

Rüdiger, C., Calvet, J.-C., Gruhier, C., Holmes, T. R. H., De Jeu, R. A. M., and Wagner, W.: An intercomparison of ERS-Scat and AMSR-E soil moisture observations with model simulations over France, J. Hydrometeorol., 10, 431-447, doi:10.1175/2008JHM997.1, 2009.

Rodriguez-Iturbe, I., Entekhabi, D., and Bras, R. L.: Nonlinear dynamics of soil moisture at climate scales 1 . Stochastic analysis, Water Resour. Res., 27, 1899-1906, 1991.

Santos, M. J., Veríssimo, R., Fernandes, S., Orlando, M., and Rodrigues, R.: Overview of regional meteorological drought analysis on Western Europe, Technical Report to the ARIDE project no. 10, Instituto de Água (INAG), Lisbon, Portugal, http://www.hydrology.uni-freiburg.de/forsch/ aride/navigation/publications/pdfs/aride-techrep10.pdf, last access: 5 March 2010, 2000.

Santos, M. J., Veríssimo, R., Fernandes, S., Orlando, M., and Rodrigues, R.: Meteorological droughts focused on a pan-European context, in: FRIEND 2002 - REgional Hydrology: Bridging the Gap between Research and Practice, edited by: van Lanen, H. A. J. and Demuth, S., no. 274 in IAHS Red Books, IAHS, 
Wallingford, UK, 273-280, 2002.

Sauquet, E., Gottschalk, L., and Krasovskaia, I.: Estimating mean monthly runoff at ungauged locations: an application to France, Hydrol. Res., 39, 403-423, doi:10.2166/nh.2008.331, 2008.

Sheffield, J. and Wood, E. F.: Characteristics of global and regional drought, 1950-2000: Analysis of soil moisture data from off-line simulation of the terrestrial hydrologic cycle, J. Geophys. Res., 112, D17115, doi:10.1029/2006JD008288, 2007.

Sheffield, J., Goteti, G., Wen, F., and Wood, E. F.: A simulated soil moisture based drought analysis for the United States, J. Geophys. Res., 109, D24108, doi:10.1029/2004JD005182, 2004.

Sheffield, J., Goteti, G., and Wood, E. F.: Development of a 50year high-resolution global dataset of meteorological forcings for land, J. Clim., 19, 3088-3111, doi:10.1175/JCLI3790.1, 2006.

Sheffield, J., Andreadis, K. M., Wood, E. F., and Lettenmaier, D. P.: Global and continental drought in the second half of the 20th century: severity-area-duration analysis and temporal variability of large-scale events, J. Clim., 22, 1962-1981, doi:10.1175/2008JCLI2722.1, 2009.

Shukla, S. and Wood, A. W.: Use of a standardized runoff index for characterizing hydrologic drought, Geophys. Res. Lett., 35, L02405, doi:10.1029/2007GL032487, 2008.

Snelder, T. H., Lamouroux, N., Leathwick, J. R., Pella, H., Sauquet, E., and Shankar, U.: Predictive mapping of the natural flow regimes of France, J. Hydrol., 373, 57-67, doi:10.1016/j.jhydrol.2009.04.011, 2009.

Soubeyroux, J.-M., Martin, E., Franchistéguy, L., Habets, F., Noilhan, J., Baillon, M., Regimbeau, F., Vidal, J.-P., Le Moigne, P., and Morel, S.: Safran-Isba-Modcou (SIM) - Un outil pour le suivi hydrométéorologique opérationnel et les études (Translation: A hydrometeorological tool for operational monitoring and research: the Safran-Isba-Modcou application), La Météorologie, 63, 40-45, 2008 (in French).

Soulé, P. T.: Spatial patterns of drought frequency and duration in the contiguous USA based on multiple drought event definitions, Int. J. Climatol., 12, 11-24, doi:10.1002/joc.3370120103, 1992.

Stahl, K.: Hydrological drought - A study across Europe, PhD Thesis, Albert-Ludwigs-Universität Freiburg, http://www.freidok. uni-freiburg.de/volltexte/202/pdf/stahl-diss.pdf, last access: 5 March 2010, 2001.

Stahl, K. and Demuth, S.: Method for regional classification of streamflow drought series: Cluster analysis, Technical Report to the ARIDE Project no. 1, Institute of Hydrology, University of Freiburg, Freiburg, Germany, http://www.hydrology.uni-freiburg.de/forsch/aride/navigation/ publications/pdfs/aride-techrep1.pdf, last access: 5 March 2010, 1999.

Svoboda, M., LeComte, D., Hayes, M., Heim, R., Gleason, K., Angel, J., Rippey, B., Tinker, R., Palecki, M., Stooksbury, D., Miskus, D., and Stephens, S.: The drought monitor, Bull. Am. Meteor. Soc., 83, 1181-1190, doi:10.1175/15200477(2002)083<1181:TDM>2.3.CO;2, 2002.

Tallaksen, L. M., Hisdal, H., and van Lanen, A. J. H.: Space-time modelling of catchment scale drought characteristics, J. Hydrol., 375, 363-372, doi:10.1016/j.jhydrol.2009.06.032, 2009.

Trnka, M., Dubrovský, M., Svoboda, M., Semerádová, D., Hayes, M., Žalud, Z., and Wilhite, D.: Developing a regional drought climatology for the Czech Republic, Int. J. Climatol., 29, 863883, doi:10.1002/joc.1745, 2009. van der Schrier, G., Efthymiadis, D., Briffa, K. R., and Jones, P. D.: European Alpine moisture variability for 1800-2003, International J. Climatol., 27, 415-427, doi:10.1002/joc.1411, 2007.

Vautard, R., Yiou, P., D’Andrea, F., de Noblet, N., Viovy, N., Cassou, C., Polcher, J., Ciais, P., Kageyama, M., and Fan, Y.: Summertime European heat and drought waves induced by wintertime Mediterranean rainfall deficit, Geophys. Res. Lett., 34, L07711, doi:10.1029/2006GL028001, 2007.

Vicente-Serrano, S. M.: Differences in spatial patterns of drought on different time scales: An analysis of the Iberian Peninsula, Water Res. Manage., 20, 37-60, doi:10.1007/s11269-006-29748, 2006.

Vicente-Serrano, S. M. and López-Moreno, J. I.: Hydrological response to different time scales of climatological drought: an evaluation of the Standardized Precipitation Index in a mountainous Mediterranean basin, Hydrol. Earth Syst. Sci., 9, 523-533, 2005, http://www.hydrol-earth-syst-sci.net/9/523/2005/.

Vidal, J.-P. and Moisselin, J.-M.: Impact du changement climatique sur les sécheresses en France (Translation: Impact of climate change on droughts in France), in: Actes du XXIe colloque de l'Association Internationale de Climatologie: Climat et risques climatiques en Méditerranée, edited by: Vinet, F., AIC, Montpellier, France, 655-660 (in French), 2008.

Vidal, J.-P. and Soubeyroux, J.-M.: Impact du changement climatique en France sur la sécheresse et l'eau du sol (Translation: Impact of climate change on drought and soil moisture in France), in: SEC 2008 - International Symposium - Drought and constructions, vol. 1, edited by: Magnan, J.-P., Cojean, R., Cui, Y.J., and Mestat, P., Laboratoire Central des Ponts et Chaussées, Marne-la-Vallée, France, 25-31, 2008 (in French).

Vidal, J.-P. and Wade, S. D.: A multimodel assessment of future climatological droughts in the United Kingdom, Int. J. Climatol., 29, 2056-2071, doi:10.1002/joc.1843,2009.

Vidal, J.-P., Martin, E., Baillon, M., Franchistéguy, L., and Soubeyroux, J.-M.: A 50-year high-resolution atmospheric reanalysis over France with the Safran system, Int. J. Climatol., in press, doi:10.1002/joc.2003, 2010.

Wang, A., Bohn, T. J., Mahanama, S. P., Koster, R. D., and Lettenmaier, D. P.: Multimodel ensemble reconstruction of drought over the continental United States, J. Clim., 22, 2694-2712, doi:10.1175/2008JCLI2586.1, 2009.

Wilhite, D. A. and Glantz, M. H.: Understanding the drought phenomenon: The role of definitions., Water Int., 10, 111-120, 1985.

Wilks, D. S.: Statistical methods in the atmospheric sciences, vol. 91 of International Geophysics Series, Academic Press, New York, 2nd Edn., 2006.

WMO: Manual for depth-area-duration analysis of storm precipitation, Tech. Rep. 237.TP.129, World Meteorological Organization, Geneva, Switzerland, 1969.

Zaidman, M. D. and Rees, H. G.: Spatial patterns of streamflow drought in Western Europe 1960-1995, Technical Report to the ARIDE project no. 8, Centre for Ecology and Hydrology, Wallingford, UK, http://www.hydrology.uni-freiburg.de/forsch/ aride/navigation/publications/pdfs/aride-techrep8.pdf, last access: 5 March 2010, 2000.

Zaidman, M. D., Rees, H. G., and Young, A. R.: Spatio-temporal development of streamflow droughts in north-west Europe, Hydrol. Earth Syst. Sci., 6, 733-751, 2002, http://www.hydrol-earth-syst-sci.net/6/733/2002/. 